\title{
MEDIAEVAL SETTLEMENT AND NECROPOLIS AT NAJEVA CIGLANA SITE IN PANČEVO (SOUTHWESTERN BANAT): EXCAVATIONS IN 2003 AND 2004
}

\author{
Dejan RADIČEVIĆ \\ Vojislav ĐORĐEVIĆ \\ Jelena ĐORĐEVIĆ
}

\section{AȘEZAREA ȘI NECROPOLA MEDIEVALĀ „NAJEVA CIGLANA” DE LA PANČEVO (BANATUL DE SUD-VEST): SĂPĂTURILE DIN 2003 \$ุI 2004}

Situl „Najeva ciglana“ se află la marginea de sud a localităţii Pančevo, de-a lungul colţului vestic al suburbiei Topola (Pl. 1). Ca urmare a activităţii intensive a fabricii de cărămizi, o mare parte a sitului a fost distrus, înainte de începerea săpăturilor. Din sit se mai păstrează doar o fâşie îngustă, de-a lungul mlaştinii Topola. În 2003 şi 2004 zona a fost cercetată sistematic, prin câteva secţiuni (PI. 2). În ciuda suprafeţei mici care a fost cercetată, complexele arheologice descoperite sunt suficiente pentru a dovedi existența unei așezări medievale, a cărei existentă se întinde, cu întreruperi, din secolul al X-lea până în secolele XV-XVI. Pe toată durata sa, aşezarea şi-a păstrat aceeaşi poziţie, pe malul înalt al terenului mlăştinos, nu departe de confluența râului Timiş cu Dunărea. Cel mai vechi complex, locuinţa 3 , şi-a încheiat existenţa în ultimele decenii ale secolului al X-lea şi la începutul secolului al XI-lea. Următoarea etapă de funcţionare a aşezării este datată în secolul al XII-lea şi la începutul secolului al XIII-lea, pe baza locuinței 1 și a cuptorului 1, împreună cu vatra alăturată. Ultimul nivel al aşezării este dovedit de locuinta 2, datată în general din secolul al XIV-lea până la începutul secolului al XVI-lea. În ultima fază, în partea NV a sitului a fucţionat o necropolă, ce suprapunea resturile locuinţelor 1 şi 3 . Necropola a fost doar parţial cercetată. Faptul că mormintele se află la aproximativ $100 \mathrm{~m}$ NE de locuinţa 2 , coroborat cu datarea lor, în general, în aceeaşi perioadă, sunt argumente în favoarea ipotezei că necropola a aparţinut aceleiaşi aşezări.

CUVINTE CHEIE: Banatul sud-vestic, Pančevo, situl Najeva ciglana, aşezare, necropolă, secolele XXV/XVI.

KEYWORDS: Southwestern Banat, Pančevo, Najeva ciglana site, settlement, necropolis, $10^{\text {th }}-15 / 16^{\text {th }}$ century.

The archaeological site Najeva ciglana in Pančevo has been known in serbian archaeological literature for a long time. Since the first archaeological excavations, which were carried out on this site in 1947 , began the modern study of medieval settlements in today Vojvodina. Although the excavations have included a relatively small area, they have resulted in important discoveries on "former populations, especially on the Slavs at the beginning of their living in these regions"1.

The site is situated on the south periphery of Pančevo, spreading out along the western edge of the suburb of Topola (PI. 1). It is located on the high bank of one of the old by- channels of the river Tamiš, known as Topola marsh, which used to enclose the site in the past secluding it from the surrounding marshy terrain towards the main flow of the river Tamiš and the Danube. The present Tamiš-Danube confluence lies at about 1.5 $\mathrm{km}$ to the west. The surface of the site is covered by a large excavation of the former brick factory which was known under different names: Pantina ciglana, Najeva ciglana, Donjovaroška ciglana, Ciglana Skanovski and, at the end of the Second World War, as Tamiš Industry of Tiles and Bricks.

The first data on this archaeological site have been recorded by $F$. Mileker indicating prehistorically finds from the site of Pantina

\footnotetext{
${ }^{\prime}$ Мано-Зиси et alii, 1948, 53-95.
} 
ciglana in the south part of the town. ${ }^{2}$ By the Second World War, an important number of objects from the different prehistoric periods, the classical period and the Middle Ages became part of the collection of the Pancevo Museum, which clearly indicated the existence of an important multilayer site. Unfortunately, due to the intensive operation of the brick factory, a great part of the site had been destroyed before the first excavations were carried out. It was the vulnerability of the site that motivated the beginning of rescue excavations in $1947 .^{3}$

The excavations were carried out in the north part of the site, between the first houses of Topola suburb and the river Tamiš. There was excavated a brick trench containing traces of pits, hearths and graves dug into the loess subsoil. On the west side of the section, there were found the remains of a prehistoric settlement and a late antique necropolis. Traces of an antique settlement were located at the central part of the terrain and were spreading out towards the East, where, quite near the first houses of the Topola suburb, were discovered the remains of a medieval settlement. Between the medieval settlement and the late antique necropolis, there were found the graves attributed to an early medieval necropolis. There are two houses, two ovens, two hearths outside of the houses and three waste pits which are considered to be a part of the medieval settlement. It was roughly dated to the $9^{\text {th }}$ century, although it is possible that certain phenomena, especially among pottery finds, could be dated to an earlier period. It is assumed that only the periphery of the bigger settlement, whose central part is situated under the settlement of Topola, has been explored ${ }^{4}$.

Although the extreme importance of this site has been confirmed by test excavations, its deterioration continued over the next years due to the renewed operation of "Tamiš

\footnotetext{
${ }^{2}$ Milleker 1897, 88.

${ }^{3}$ Excavations were carried out in the organization of the then Art Museum in Belgrade and the Town Museum in Pančevo. Members of the expert team were: custodian $Đ$. Mano-Zisi and assistents M. Ljubinković, M. Garašanin and J. Kovačević from the Art Museum and custodian and director of the Pančevo museum, $R$. Veselinović.

${ }^{4}$ Мано-Зиси et alii, 1948, 53-59.
}

industry of tiles and bricks“. Nowadays, it is difficult to define precisely the surface destroyed by the years-long operation of the brick plant. Nevertheless, according to the surface of the previous excavation it may be assumed that the destroyed surface amounted to about $500 \times 500 \mathrm{~m}$. The remaining part of the site now represents only a narrow stretch along the Topola marsh, west of the industrial railway track of the "Industry of Nitrogenbased Fertilizers". It is about $300 \mathrm{~m}$ long and up to $150 \mathrm{~m}$ wide surface, which is situated about $350 \mathrm{~m}$ south of the estimated location of the brick plant section where archaeological excavations were carried out in 1947.

In 2003 and 2004, in that area, there were carried out excavations (Pl. 2) in the organization of the National Museum of Pančevo, in cooperation with the Archaeology Department of the Faculty of Philosophy of the Belgrade University. The objective of those trench-type excavations was to define stratigraphic situation and to elaborate the appropriate archaeological documentation for the remaining part of the site. Regardless of the modest scope of excavations, there was found a multilayer site, including cultural deposits and structures confirming the presence of life in a large chronological range, from the Bronze Age to the Middle Ages. ${ }^{5}$

During the campaign of 2003 , there were open two trenches and a test surface forming an overall excavated area of $86 \mathrm{~m}^{2}$. The trench $1 / 2003,35 \times 1 \mathrm{~m}$ in dimensions, oriented in the northeast-southwest direction, showed a complex stratigraphy with traces of life from the prehistoric period, antique period and the Middle Ages (Pl. 3). A medieval deposit was found across the entire surface of the excavation; up to the average depth of $0.6 \mathrm{~m}$. Preliminary results show two different life phases within that layer. The earlier phase, roughly dated from the $11^{\text {th }}$ to the $13^{\text {th }}$ century, was defined by three hearths in the open air and one dugout oven, while

\footnotetext{
${ }^{5}$ Đorđević, Đorđević, Radičević 2005, 263-265, Fig. 3, 4; Ђорђевић 2007, 50-54; Ђорђевић, Ђорђевић, Радичевић 2008, 88-90; Ђорђевић 2009, 7-14.
} 
the later phase was defined by late medieval pottery shards found in the cultural layer. ${ }^{6}$

The hearths were found at an average depth of $0.5 \mathrm{~m}$, at a mutual distance of about 1 to $2 \mathrm{~m}$. They were made out of clay and have circular or oval floors of about $1 \mathrm{~m}$ in diameter. Inside one of the hearth there were found parts of a cauldron and pot (PI. 14/1213). They were manufactured on a slow wheel out of refined clay with addition of sand and they were gray ware. Both vessels contain an ornament consisting of single horizontally incised lines.

In close proximity of the hearths, there was found a dugout circular oven with dome superstructure, designated as the oven 1 (PI. 4/1-2). Oval fired floor of an about $1.2 \mathrm{~m}$ in diameter and $8 \mathrm{~cm}$ thick, was found at a relative depth of $0.6 \mathrm{~m}$. The oven had a partially preserved $5 \mathrm{~cm}$ thick dome structure. On the northeast side there was an oval access space, $2.5 \mathrm{~m}$ long and buried up to 0.5 $\mathrm{m}$. The edges of the excavation were lined by sills, while the floor was made of compacted earth. On both sides of the opening of the oven there were two irregularly pits intended to ash refusal during the cleaning of the oven. Within the cultural layer surrounding the oven, in the earth used for backfilling of the excavation, as well as inside the oven itself, there was found a certain quantity of pottery shards (Pl. 12/1-14, 13/1-10, 14/1-11).

In the same year 2003, at about $60 \mathrm{~m}$ northeast of the trench $1 / 2003$ there was opened the test surface $1 / 2003$ which also confirmed a complex stratigraphic situation (Pl. 2-3). On the small excavated surface of $19 \mathrm{~m}^{2}$ there was discovered a prehistoric layer, a late antique pit, a medieval house dated to the $12^{\text {th }}$ and the first half of the $13^{\text {th }}$ century and a later necropolis buried over the house. ${ }^{7}$

The medieval dwelling, designated as the house 1 , represents a semi-dugout house discovered at a relative depth of $0.85 \mathrm{~m}(\mathbf{P I}$. 5/1-2). The floor was made of yellow compacted clay at a depth of $1.25 \mathrm{~m}$. The house had a trapezoidal base, $3.5 \times 3.2 \mathrm{~m}$ in dimensions, whose longer sides were oriented in the direction north-south. At the floor

\footnotetext{
${ }^{6}$ Ђорђевић 2007, 50, сл. 1.

${ }^{7}$ Ђорђевић 2007, 50-52; Ђорђевић 2009, 7-14.
}

level, in the northeast corner of the house there were remains of a smaller semi-circular fireplace, $0.45 \times 0.50 \mathrm{~m}$ in dimensions. The hearth has been poorly preserved and only traces of its fired floor have been found. In the eastem part of the house, there was discovered a smaller rectangular pit, $0.70 \times$ $0.50 \mathrm{~m}$ in dimensions, buried under the house. That dug out was an integral part of the house and it could have been used as a smaller store room inside the house. In the cavity filling of the building there has been found an important quantity of pottery material, animal bones, pieces of plaster with imprints of brushwood, a clay spindle-whorl made out of a pot wall, bone hilt of a knife, fragments of grindstones and several unidentified iron objects (Pl. 15-20). The floor and the south edge of the house were damaged during the placing of two later graves, while next to the east edge of the building there was another grave which belonged to the same necropolis.

The next year, in 2004, excavations were continued on both parts of the site. There were open two trenches and one test surface: the total excavated surface was $94 \mathrm{~m}^{2}$ (Pls. 23). On the west part of the preserved part of the site, there was explored the trench $3 / 2004$, $25 \mathrm{~m}$ long and $1 \mathrm{~m}$ wide, oriented in he northeast-southwest direction. It was open 10 m west of the trench $1 / 2003$ and its northeast section concurs with the southwest edge of the trench $1 / 2003$.

At the northeast end of the trench, there were discovered the remains of a groundlevel dwelling (house 2), which was roughly dated to the period from the $14^{\text {th }}$ to the $15^{\text {th }}$ century $^{8}$. There were preserved some fragments of the floor found at a relative depth of $0.7 \mathrm{~m}$ above which were found fragments of the crumbled wall made of yellow clay, big fragments of fired earth and fragments of house plaster (PI. 6/1-2). The floor made of compacted earth, $10 \mathrm{~cm}$ thick, indicated an irregular square shaped base, $4 \times$ $4 \mathrm{~m}$ in dimensions, oriented in the northsouth direction. During excavation there were not found any pits for load bearing pillars. It was only along the north edge of the building

\footnotetext{
${ }^{8}$ Ђорђевнћ, Ђорђевић, Радичевић 2008, 88-89.
} 
that was discovered a circular pit, of $0.5 \mathrm{~m}$ in diameter, buried at $0.2-0.4 \mathrm{~m}$, which could have been used as a store room - storage pit inside the house. During the excavation of the cultural deposit formed above the house, especially above the floor and inside the storage pit, there was found a great number of pottery fragments (Pls. 21-23), but also other different objects which could be identified as parts of the household furniture: iron knives (Pl. 24/8-10), iron nails (Pl. 24/2-5), fragments of iron tools (Pl. 24/1, 6-7), grindstones (PI. 24/14) and clay spindlewhorl (PI. 24/11), as well as two glass pearls (PI. 24/12-13).

In the north end of the preserved part of the site, in close proximity to the section of old brick excavation, and partly in the area of the test surface $1 / 2003$, there was opened the trench $4 / 2004,12 \times 1.5 \mathrm{~m}$ in dimensions, oriented in the northeast - southwest direction (Pls. 2-3). Some $10 \mathrm{~m}$ west of this trench there was the test surface $2 / 2004,5 \times 2 \mathrm{~m}$ in dimensions, oriented in almost the same direction. In the area of both excavations, the spreading of the necropolis discovered in the test surface $1 / 2003$ was roughly confirmed and inside the test surface 2/2004 there were discovered the remains of an earlier medieval dwelling, designated as the house 3 , which was preliminary dated to the period from the $9^{\text {th }}$ to 10 th century. ${ }^{9}$ Those are the remains of a semi-dugout house with a square base and about $3.3 \mathrm{~m}$ long edges (PI. 7/1-2). The dug out was detected at a relative depth of $0.90 \mathrm{~m}$, and from that level the house had been buried into the yellow-brown subsoil at $0.25-0.30$ $\mathrm{m}$. At that depth, there was a floor made out of well compacted earth and coated by grey clay. In the northwest part of the house, the floor has sagged over time and sunk for about $0.1 \mathrm{~m}$ into the backfilling of the late classical circular grain storage pit above which the house was constructed.

The finds from the house consisted only of pottery shards and a bone borer (Pls. 1011). At the floor level, in the northeast comer, there was a fireplace about $1 \times 1 \mathrm{~m}$ in dimensions, including a fired floor covered by a concentration of broken stones, with

\footnotetext{
${ }^{9}$ Ђорђевић, Ђорђевић, Радичевић 2008, 89-90.
}

fragments of broken dome-shaped lid. At the opposite end of the building, in the southwest corner, there were found the remains of another fireplace without stones, only with a fired floor, approximately $0.70 \times 0.70$ in dimensions. In the northwest part of the house, approximately along the northwestsoutheast axis, there were two pits, probably made out of wooden pillars supporting the roof structure. The pits were buried into the floor at the depths of $0.80 \mathrm{~m}$ and $0.50 \mathrm{~m}$ and their upper part was of an irregular rectangular-circular shape, while the lower part had a more regular circular base. Their upper diameter was about $0.40 \mathrm{~m}$, while they were narrowing towards the bottom up to $0.25-0.30 \mathrm{~m}$. Besides those two biggest and the most deeply pits, along the northwest and southwest border of the house there were found several pits with smaller diameter made of pillars which probably used to support the walls. Along the southwest border of the house there was discovered a shallower $0.20 \mathrm{~m}$ wide trench which contained pits for pillars of a smaller diameter. The entrance of the house could not be defined precisely, but, according to the disposition of hearth, it is clear that it could have been placed either on the north or on the south side of the building. Next to the northeast corner of the house there was a regularly buried circular grain storage pit, but, since there were no small finds which could chronologically define it, it is still not clear whether it was a part of the house or it originates from another period.

According to the pottery finds from the discovered dwellings, it is clear that they do not originate from the same period. Only the house 1 and oven 1, including the nearby hearth, could be considered as contemporaneous or very close regarding the time period, on the basis of almost identical material. Due to the absence of other objects which are more chronologically sensitive, the dating was done according to technologicaltypological characteristics of the pottery material.

The oldest medieval complex explored at the site is the house 3 . In the earth covering the house, there were found 119 pottery shards originating from at least 10 pots manufactured on a slow wheel out of clay 
with addition of sand (Pl. 10/1-20, 11/1-10). They were mostly brown, grey and ochre ware. The interior side of three fragments showed traces of surfacing by a comb-shaped tool and on one of the fragments there were found the traces of surfacing by a larger tool. Only two pottery shards, coming from pots with thicker walls of a lesser quality, manufactured on a slower potter's wheel, differed in material. Both fragments were decorated by a thick comb producing a combination of wavy and horizontal lines. They are ochre-black ware and one of the shards contains crushed pottery.

Two different groups of pots can be sorted out, those with a large opening of 18$19 \mathrm{~cm}$ in diameter (Pl. 10/2-5) and those with a smaller opening of $10-14.5 \mathrm{~cm}$ in diameter (Pl. 10/7-10). Both groups of pots have short and slanted averted rims, with simple profiling and straight cut or rounded rim. Their bottoms are plane and have about $8-10$ $\mathrm{cm}$ in diameter.

A bit more than a half of the total number of discovered shards contained ornaments incised by a comb, while only four fragments contained single horizontal lines. The upper part of pots was decorated by a comb, but some of the shards show that the ornament could have also been incised on the lower part, sometimes almost to the bottom. Almost half of the decorated fragments contain an ornament consisting of wavy lines, while the rest of the omaments consist of horizontally incised lines and a combination of wavy and horizontal lines. On one of the fragments, wavy line was incised over the horizontal lines and on two other fragments horizontal lines were incised over the wavy line.

Among the discovered shards there is a small group which differs from the rest of the material by its typological-technological characteristics and it is possible that it represents an intrusion from a later layer from the $12^{\text {th }}$ to $13^{\text {th }}$ century, which could have happened during placing of later graves. This group has been defined by two cauldron fragments and four fragments coming from the bellies of pots made out of clay mixed with crushed mica. This group includes a pot shard decorated by dimples (PI. 10/1), as well as a fragment coming probably from the bottom of a jug manufactured on a fast wheel out of well refined clay mixed with fine sand. It is characterized by dark ochre ware, as well as by an ornament consisting of horizontal glazed stripes.

On the floor of the house and around the hearth, there were found 33 pottery shards originating from at least 6 different pots (PI. 11/13-15). All of them were manufactured on a slow wheel out of clay mixed with fine or medium sand. Interior side of certain fragments contains horizontal traces of polishing by a tool. They are mostly grey to ochre ware. From the total number of the found pottery shards, there are 20 fragments containing incised ornaments, of which 18 were made by a comb, while on the other 2 ornaments were made by a single-point tool. Among the decorated fragments, most of them have horizontally incised wavy lines, as well as horizontal lines or a combination of those two omaments. On one of the fragments decorated by a pointed tool there is a single wavy line, while the second contains a horizontally incised line. There is only one fragment which has horizontal stripes with wavy or slanted lines over them made by a comb.

Within the pottery material found in the house, there are several exceptions represented by fragments of conic coarse earthen lid (in Serbian sač or vršnik) which were found near the bigger hearth (PI. 11/1112). They were manufactured without use of potter's wheel out of badly refined clay mixed with sand, organic materials and crushed pottery. It is interesting that during the manufacture of the lid, clay was mixed with pot fragments produced on a hand potter's wheel. Certain fragments still contain the original ornament incised by a comb.

According to its typological characteristics, pottery found in the house 3 could be roughly dated to the period from the $9^{\text {th }}$ to the $11^{\text {th }}$ century. The most general common characteristics can be found within the pottery discovered on numerous sites originating from the same period throughout the Middle Danube Basin. However, for more precise dating, the most important are the closest territorial analogies. Pots having similar characteristics originate from the site 
Livade belonging to the municipality of the neighboring Starčevo. Those are the finds from the later level of the medieval settlement, roughly dated to the period from the $9^{\text {th }}$ to the $10^{\text {th }}$ century. The end of life in this settlement was dated by an anonymous follis belonging to A2 class, excavated in the period from 976 to $1030 / 35 .{ }^{10}$ Similar pots were found in several sites in the southeast part of the Serbian Banat where they were also dated from the $9^{\text {th }}$ to the $10^{\text {th }}$ century. ${ }^{11}$ Close analogies have also been found on the right bank of the Danube, in Belgrade and its closest surroundings. Those found on the Belgrade Fortress originate form the earlier deposits of a settlement in the area of the Westem Lower Town and the Lower City. As stated before, very important finds used for dating of those deposits are the coins of the Byzantine Emperor Roman I (931-944) ${ }^{12}$. Analogies have also been found in the medieval settlements upstream and downstream of Belgrade. Those found on the site of Šljunkara near Zemun originate from buildings which have been dated to the $9^{\text {th }}$ century, while on the site of Reka in Vinča, they were found in the house 3 , which has been dated to the last decades of the $10^{\text {th }}$ century or, at the latest, to the first-second decade of the $11^{\text {th }}$ century. ${ }^{13}$

A more precise dating of the pottery from the house 3 would place it within the limits of the $10^{\text {th }}$ century, from the late $9^{\text {th }}$ century up to the first decades of the $11^{\text {th }}$ century. This structure does not contain any finds showing distinct characteristics of the late $11^{\text {th }}$ century. On the other hand, it is also characterized by the absence of handmade pots, which represents an important characteristic of settlements dated from the $8^{\text {th }}$ to the $9^{\text {th }}$ century. ${ }^{14} \mathrm{~A}$ great number of handmade pots were found in the earlier level of the mentioned settlement on the site of Livade in Starčevo, as well as inside the building 1

\footnotetext{
${ }^{10}$ Ђорђевић, Ђорђевић 2009, 27-28; Ђорђевић 2010, 223.

" Ђорђевић 2000, 57, Т. XII/3, 59, Т. XIV/3, 4, 7, 9, $11,14,60$, T. XV/8.

${ }^{12}$ Бикић 1994, 15-17, сл. 2/1, 7-17.

13 Јанковић 1995-1996, 124-127, T. III-VIII; Јанковић, Јанковић 1990,84 , кат. 35-49; Јанковић $1997,46$.

${ }^{14}$ Станојевић 1986-1987, 119-131.
}

explored on the site of Velike njive in Dobrica, which could be dated to the $9^{\text {th }}$ century. ${ }^{15}$ The only vessels made without the use of potter's wheels among the material from the house 3 are coarse earthen lid (PI. 11/11-12). Regarding their manufacture and typology, they are very similar to lid found in almost all of the mentioned settlements from the $8^{\text {th }}$ to the $9^{\text {th }}$ century, where they were discovered together with handmade pots. ${ }^{16}$ In the older literature, there has already been stated that handmade pottery on the sites of Srem and Banat can be traced up to the $10^{\text {th }}$ century. ${ }^{17}$ As far as the use of coarse earthen lid is concerned, this is exactly what has been confirmed by the finds from the house 3 in Najeva ciglana. During their manufacture, clay was mixed by fragments of pots manufactured on a slow wheel and decorated by a comb, the same as those which represent the rest of the material found in the same archaeological complex.

The next stage of life on the site, in the west part, can be identified by the oven 1 and the surrounding hearth, as well as by the house 1 explored in its northeast comer. In the cultural layer around the oven 1, there have been found 41 pottery fragments, of which 29 are typologically considered as parts of pots, and 11 as parts of cauldrons (Pls. 12-13). Both vessels are mostly grayish to ochre ware. All vessels were manufactured on hand potter's wheels, mostly out of refined clay with addition of sand, while the fragments containing crushed mica represent about $22 \%$ of the total number of pots and cauldrons. The exception among this material is a fragment originating probably from the bottom of a jug or a carafe manufactured on a fast wheel and with almost black exterior glazing (PI. 13/10).

Among the pots, there are those with non emphasized shoulders and bellies (PI. 12/1) and those with slightly emphasized shoulders,

\footnotetext{
${ }^{15}$ Ђорђевић 2010, 214. Excavations in Dobrica were published in 1993, but the results have not been published yet. The material is kept in the Museum of Vojvodina in Novi Sad and we are able to consult it thanks to the kindness of the manager of excavations, $S$. Trifunović.

${ }_{16}$ Станојевић 1986-1987, 125, сл. 9/2, Т: X/2; Јанковић 1995-1996, T: V/8, VL/7.

${ }^{17}$ Јанковић 1997, 48.
} 
with short rims which are either attenuated or erected (Pl. 12/2-3). Most of them are not decorated or contain simple ornaments consisting of a row of dimples imprinted by a needle. There are also different larger pots with emphasized shoulders and ornaments made by a needle consisting of single horizontal lines or dimples above horizontal lines (Pl. 12/7-8, 14/1, 6).

Different types of incised ornaments have been found on 18 pot shards and 3 cauldron fragments. Most of the pots contain a single ornament incised by a pointed tool consisting of stripes of horizontal lines or wavy lines (about 60\%), and rarely a wavy line or horizontal lines incised by a comb. There are several cases of ornaments consisting of dimples or dimples combined with horizontally incised lines, as well as of a row of slanted lines. As far as cauldrons are concerned, decorated fragments contain only an ornament consisting of horizontally incised lines.

In the earth filling the access space to the oven and inside of the oven, there were found 87 pottery fragments, of which 76 were considered to belong to pots and 10 to cauldrons (PI. 14/1-11). An exception among this material represents a small part of a bottom belonging probably to a jug or carafe manufactured on a fast potter's wheel, with light ochre exterior and grey interior surface and decorated by polishing of the outside surface. Pots and cauldrons are mostly grayish and ochre ware. The shards originate from about ten different pots and the same number of cauldrons. The pots were made on a hand potter's wheel, mostly out of refined clay with addition of sand, while there are only three pottery shards which contain crushed mica. Unlike the pot fragments, among the cauldron fragments there is approximately the same number of those made with addition of sand and those made with addition of crushed mica. Among the cauldrons, there is an example containing plenty of sand, gray ware and decorated with multiple wavy lines on the upper surface of the rim made by a comb (Pl. 14/10).

There are 21 fragments of pots with different types of incised ornaments. By far the most represented motive (about $76 \%$ ) is the one consisting of a single ormament made mostly of horizontally incised lines. Multiple ornaments made by a comb consisting of wavy or horizontal lines were found only on 3 fragments. There was also found an ornament consisting of a shallow horizontal groove or slanted incised lines. When we are talking about ornaments found on cauldrons, apart from the mentioned cauldron decorated by a wavy line, there is only one shard decorated by an ormament consisting of horizontally incised lines.

In the layers excavated above the defined level of the dugout belonging to the house 1 , there were found 438 pottery shards, of which 366 pottery shards (about 83\%) typologically belong to pots and 69 fragments belong to cauldrons (Pls. 15-17). There are three pottery shards which belong to jugs and only one which is considered to belong to a bowl. Pottery shards considered as parts of pots and cauldrons originate from at least 63 different pots and 41 cauldrons. All those vessels were made on a slow wheel out of refined clay with addition of sand, while pot and cauldron shards containing a bigger quantity of crushed mica (only two pot fragments and two cauldron fragments) are extremely rare. Regarding the manufacture, there is only one jug shard which differs from the others. It was manufactured on a fast wheel and has glazed exterior surface. Another fragment considered to be a part of a carafe was manufactured on a slow potter's wheel out of clay with addition of calcite, sand and gravel and it has ornaments consisting of rows of single horizontal lines (Pl. 17/10).

Among the total number of discovered pottery shards, there are 233 of them with different types of incised ornaments (about $53 \%$ ). Most of the pots are decorated by a single ornament incised by a pointed tool (about $70 \%$ of the total number of decorated pottery shards), usually consisting of stripes of horizontally incised lines and quite more rarely of a wavy line or combination of a wavy line and horizontally incised line (only about $7 \%$ of the total number of pottery shards were decorated in this manner).

Incised ornaments made by a comb have been found on 54 pottery shards (about 23\% 
of the total number of decorated pottery shards), namely about the same number of those consisting of stripes of wavy lines or horizontal lines (approximately the same number, in total about $90 \%$ of the total number of pottery shards decorated by a comb), while pottery shards containing a combination of both motives are quite more rare. There is only one case of ornament consisting of combination of a single wavy line and a stripe of horizontal lines incised by a comb.

Besides incised lines, there is quite a smaller number of omaments consisting of dimples or a combination of dimples and single incised horizontal line (all together about $7 \%$ of the total number of decorated fragments). There are very little fragments with ornaments consisting of dimples made by a toothed wheel or slanted incised lines (only two fragments from the total number).

Among the pottery shards attributed to cauldrons, there are 25 fragments (about $36 \%$ ) containing an ornament made by carving before baking, the same as on pots. Most of those pottery shards contain a single ornament made by a pointed tool consisting of a stripe of horizontal lines incised on the upper part of the cauldron. Stripes of horizontal lines incised by a comb have been found only on three fragments and the same number of fragments contains an ornament consisting of a horizontal row of dimples incised under the rim of the cauldron.

Most of the rare fragments of carafes and bowls, with the exception of the mentioned glazed carafe manufactured on a foot potter's wheel, were made on a slow wheel out of a material which is not very different from the one used for pots and cauldrons. As far as decoration of these vessels is concerned, there is only one pottery shard with an ornament consisting of a stripe of single horizontally incised lines.

In dark brown earth which used to fill in the building, there were found 436 pottery fragments, of which 405 (about $93 \%$ ) were typologically attributed to pots, while the rest was attributed to cauldrons (Pls. 18-19). There was only one shard which belonged to a bowl. Those are the fragments of at least 26 pots and 12 cauldrons manufactured on a slow wheel out of refined clay with addition of fine or coarse sand.

From the total number of discovered pottery shards, there are 93 (about 21\%) of them containing different types of incised omaments. Pottery shards attributed to cauldrons are mostly non decorated, but if there was found an ornament, which was the case of only 6 fragments, it consisted of a single incised horizontal line on the upper part of the vessel. Only in one case, the ornament consisted of single wavy lines incised by a sharp tool.

Most of the pots contain a single incised ornament (about $74 \%$ of the total number of decorated fragments) consisting of horizontal lines (about $87 \%$ of the total number of fragments decorated in this manner) and quite rarely a wavy line or a combination of a horizontal and wavy line. The comb was used much less frequently (about $20 \%$ ), namely for making stripes of horizontal and wavy lines which were found in approximately the same number. There are only five fragments decorated by dimples, usually combined with horizontally incised lines and there is only one shard decorated by dimples made by a toothed wheel. There are isolated cases of ornaments consisting of a single wavy line under which, on the shoulder of a pot, can be found multiple parallel lines or a row of cuts imprinted by a sharp tool, as well as a multiple wavy line incised by a comb on the belly. There is an isolated phenomenon represented by a pot with two rows of long slanted cuts separated by a row of dots, while under this ornament there is a stripe of multiple horizontal incised lines.

The pots may be classified in three main groups according to their shape. The first group includes pots with low and dropped shoulder (PI. 15/3-4, 18/2, 4), with averted rims which can be simple and non-modeled or with a groove designed to receive a lid. They have various ornaments consisting of rows of dimples realized above multiple wavy lines or simple horizontal lines or rows of perforations made by a toothed wheel. The most complex ornament consists of a row of slanted dimples, pointed dimples and a single wavy line above horizontal lines. The second group includes pots with emphasized 
shoulders and slanted averted rims (Pl. 15/5, 18/1) and the third group, which is the least represented, includes spherical pots (PI. 15/1-2, 16/1). They differ from the two previous types by the material since they were made out of clay mixed with an important quantity of mica, besides sand and calcite. They were decorated by rows of single horizontal lines, sometimes with incised dimples above them. Since they have been preserved in fragments, it is not possible to define their height, but all those three groups of pots are generally small or medium size. The rims have from 11 to $18 \mathrm{~cm}$ in diameter, while the bottoms have from 6 to $10 \mathrm{~cm}$ in diameter. On certain parts of the bottom there are imprints from the upper surface of potter's wheel representing a circle or network pattern (PI. 16/6-7, 19/3-4).

There was also discovered an important number of pot shards which were very badly preserved so that it was not possible to define their shape. Among them there are those with simply averted rims, straight cut or rounded lips (Pl. 15/6-9, 18/5), as well as those with modeled rims and a groove for the lid (PI. 18/6). The exception is an orange red rim whose lip was decorated by an ornament consisting of dimples imprinted by a sharp tool.

The cauldrons had slanted or upright walls and from 22 to $31 \mathrm{~cm}$ in diameter. Their rims are very diverse. They are usually rounded inside and enlarged towards the outside, with rounded or straight cut lips (PI. 16/8-9), although there are also examples with more or less down-bent lip (PI. 17/4, 7). The cauldrons with rims which are rounded towards the outside and enlarged towards the inside are quite rare (Pl. 19/9), as well as the cauldrons with rounded rims and shallow groove on the lip (Pl. 17/3).

According to the analogies, the pottery found in the house 1 was roughly dated to the period from the $11^{\text {th }}$ to the $13^{\text {th }}$ century, or more precisely to the $12^{\text {th }}$ century and the first decades of the $13^{\text {th }}$ century. ${ }^{18}$ The same dating can be accepted for the finds from the oven 1 and the surrounding hearth. The pots manufactured in a similar manner, with

\footnotetext{
${ }^{18}$ Ђорђевић 2009, 7-14.
}

similar modeling and ornaments, have been found known on a great number of sites explored in Vojvodina, in the Romanian Banat, but also on the right bank of the Danube. They are roughly dated from the beginning of the $11^{\text {th }}$ century to the beginning or mid $13^{\text {th }}$ century. ${ }^{19}$ The closest territorial analogies have been found on the sites of Lenjinova Street and Fire House in Pančevo itself, as well as in Opovo, Dolovo, Kovin and the sites in the surroundings of Alibunar. ${ }^{20}$

In the layers and closed complexes of the mentioned sites north of the rivers Sava and Danube, besides the pots, there was also found an important number of cauldrons similar to those found in Najeva ciglana. Among the closest sites of Banat, they were found in Opovo, Dolovo, Kovin, Alibunar and Banatski Karlovac. ${ }^{21}$ According to the typology set up by M. Takač, all discovered cauldrons would belong to the type of cauldrons manufactured by imitating the samples made of metal. On the basis of finds from Opovo and its surroundings, there was sorted out a group of cauldrons with a workshop character from the surroundings of Pančevo containing characteristic single horizontal lines. ${ }^{22}$

Similar finds to those small and very rare pottery shards attributed to jugs can also be found in the same area. Jugs manufactured on a slow wheel out of well refined sandy clay are also well known in the South Banat and on the opposite bank of the Danube and they

\footnotetext{
19 Нађ 1956, Т. III/2; Станојевић 1980, Т. VII/5; Станојев 1996, 11, 1/1; Janković, Radičević 2005, 284, Fig. 7/9; Uzum 1983, 272, Fig. 6, 277, Fig. 11; Teicu, Lazarovici 1996, Fig. 36/5, Fig. 38/4; Žeravica 1974, T.I/3, T. IV/19, V/5, 7; Minić 1980, 26, T. I/2, 6, 27, II/2-3,6-7; Јанковић 1981,50 , сл. 23, 24/тип А, Б и Г, T. VII $/ 4,20,21, \mathrm{~T}$. IX/27, T. XVI/5; Поповић, Иванишевић 1988, сл. 3/1-3; Бикић 1994, 19, сл. $5 / 18-21,19$, сл. 6/7-8, 17, 19.

20 Ђорђевић 2010, 236; Манојловић 1989, 41-46; Батистић-Попадић 1988, 7-18; Зечевић 1997, 185197; Трифуновић 1989-1990, 99-130; Пашић 2001, 177-194.

${ }^{21}$ Манојловић 1989, Т. III/1, 4; Ђорђевић 2002, Т. VIII/1-2; Батистић-Попадић 1988, Т. II/6; Зечевић 1997, Т. III; Трифуновић 1989-1990, Т. XIl/2-3, XIII/1-2, XVII/5; Пашић 2001, 191, 193-194, сл. 4/1$2,6 / 9-10,7 / 10-12$.

${ }^{22}$ Takács 1986, 69-71; 98; T. 78/1, 79/1-3, 80/1-3, 81/1-2.
} 
are dated to the second half of the $12^{\text {th }}$ and the first half of the $13^{\text {th }}$ century. ${ }^{23}$ Glazed jugs manufactured on a fast wheel were found on several sites on both sides of the Danube, between Belgrade and Prahovo. ${ }^{24}$ Their appearance is connected to the renewal of the Byzantine rule on the Danube and they were used in this area until the fall of Byzantium. ${ }^{25}$

The latest medieval remains documented on the site are represented by the house 2 in the west part and graves excavated at the northeast end. In the upper layers filling the house 2 and inside the cultural deposit formed around the house, there were found 971 fragments of pottery (Pls. 21-22). By far the biggest number was attributed to pots (about 93\%) and then to jugs or carafes (about $4 \%$ ) or to lids (about $2 \%$ ), while only three fragments were attributed to beakers. There were sorted out the fragments of at least 39 pots, 7 jugs or carafes, 20 lids and 3 beakers.

All those types of vessels were manufactured on a fast potter's wheel, out of well refined earth with addition of sand. The pots are mostly grayish ware (about $56 \%$ of the total number of shards), a bit more rarely ochre-orange (about 24\%) and in different nuances of ochre (about 17\%), and the most rarely white and ochre-grey ware. The jugs or carafes are orange ware or in nuances of gray, white or ochre. The lids are in nuances of grey and ochre, while the beakers are exclusively white ware.

From the total number of pot fragments, only 50 of them were decorated, mostly by single horizontal incised lines, while a single wavy line and combination of horizontal and wavy lines were found only in single cases. There are also single cases of multiple wavy lines incised by a comb or imprints consisting of horizontal grooves made by finger.

More frequent and various modeling of the exterior surface was found on the shards attributed to jugs or beakers (about $68 \%$ of

\footnotetext{
${ }^{23}$ Зечевић 1997, 187; Пашић 2001, 192, сл. 5/6-7; Поповић, Иванишевић 1988, 152.

${ }^{24}$ Бикић 1994, сл. 20/3-4; Поповић, Иванишевић 1988,149 , сл. 19/8,10; Јанковић 1983, 12-13, 15, сл. 7/30-31; Žeravica 1974,152, T. XX/7; Uzum 1977 , Fig. 7.

${ }^{25}$ Поповић, Иванишевић 1988, 147; Бикић 1994, 54.
}

the total number of shards attributed to this type of vessels are decorated). About one half of the fragments are glazed, while there is much smaller number of painted fragments. Polishing usually combines green-brown, green, green-yellow, brown and greenbrown-yellow colours. Painting with red colour on a white surface was found on 3 fragments, while there were only single cases of painting with white colour on a red surface and with brown color on an orange surface. One handle was decorated by deeply incised slanted lines. There are single cases of parts of a jug belly decorated by a single wavy line made by a pointed tool or by finger imprints consisting of horizontal grooves. The same type of decoration by horizontal grooves was also found on beakers.

In the lowest layer of the filling and on the floor of the building, there were found 231 fragments of vessels, of which about $90 \%$ were attributed to pots and the rest to lids, jugs or beakers (Pl. 23). There is only one fragment which could be considered as part of a beaker. The discovered pottery shards originate from at least 9 pots, 11 lids and 3 jugs or carafes.

All types of vessels were manufactured on a fast wheel out of well refined clay with addition of sand. Among the fragments of pots, there is a bit more than a half of them which are grayish ware, then, there are fragments in different nuances of ochre (about 29\%), while there is a smaller number of orange ware fragments (about $11 \%$ ) or non uniform white-grey ware (about $8 \%$ ). The lids are mostly non uniform white-grey ware, while the fragments of jugs or carafes are orange or ochre ware.

From the total number of pot fragments, there are only 10 decorated shards. Most of them contain a single horizontal line and rarely imprints of horizontal grooves made by finger. The fragment attributed to a beaker contains an ornament consisting of a single horizontal line incised by a needle. Among the jugs and carafes there is a bigger number of decorated ones and the ornaments are more diverse. There are two fragments with decorations made by a needle consisting of a horizontal line of dimples, while there are 
also single cases of green-ochre glazing and painting with white color on a dark surface.

Pots can be classified according to the shape of their body and rim. Most of the pots have an emphasized shoulder on the upper part of the vessel, almost vertical neck and slanted averted rim (PI. 21/1-4, 23/1-2). They can contain an ornament on the shoulder consisting of shallow horizontal grooves or be undecorated. Their rims are short, nonmodeled, straight-cut or rounded and they can have a shallow cavity for the lid on their inner side. They have from 14 to $18 \mathrm{~cm}$ in diameter which makes them fall within the group of medium size pots. The second type includes pots with largely averted rounded or straightcut rims, which usually have a shallow cavity for the lid on their inner side (Pl. 21/6-8, 23/4-5). The diameters of those rims range between 11 and $18 \mathrm{~cm}$. A special group includes pots with sharp rims averted almost at the right angle, with rounded or straight-cut lip (PI. $21 / 5,9,16)$. The main characteristic of this group is a simple ornament consisting of wavy and horizontal lines incised by a needle. Although represented in a small number, there is also a group of pots with bigger dimensions that can be identified, with an opening diameter ranging from 18 to $23 \mathrm{~cm}(\mathbf{P l} .21 / 10$, 23/3). The rims are more complex and may be short, stubby, horizontally averted or upright, straight-cut with a groove on the top of the lip.

There are also pots with a groove on the lip of the rim, with a smaller opening diameter (PI. 21/11-12), as well as pots with modeled (Pl. 21/14-15, 23/8-9) and extremely modeled rims (Pl. 23/10-11).

Lids represent the second most common type of utensils found in the house 2. They were manufactured on a fast potter's wheel, out of well refined clay with addition of sand in all cases and fine gravel and calcite in single cases. Their colour varies from ochre to brown ware. They can be divided in two groups: hemispherical lids with rounded walls (Pl. 22/1, 23/12, 14) and conic lids with slanted walls which are represented in a greater number (PI. 22/2-5, 23/15-16). Their opening diameters range from 11 to $20 \mathrm{~cm}$. Rims of hemispherical lids are better modeled than those on conic samples. They are horizontally averted and contain grooves.
They have button shaped handles, enlarged towards the top, and some of them contain incised dimples at the edge (Pl. 22/12).

Jugs differ according to the manner of manufacture and decoration, but they can generally be divided into two groups: glazed and unglazed. There is one example glazed in different colours: ochre-yellow, olive green and light green (Pl. 22/14). Unglazed jugs have upright necks and their rims are in some cases slightly averted. They are decorated by painting with white engobe (PI. 22/16, 23/19) or by carving of horizontal lines (Pl. 23/2021). One of them was made out of white clay and decorated by painting with dark red colour (PI. 22/15).

According to the pottery, the house 2 can be dated to $14-15^{\text {th }}$ century or, at the latest, to the beginning of the $16^{\text {th }}$ century. Similar pottery, manufactured in the same manner, is characteristic for the region of the South Kingdom of Hungary in the period from the $14^{\text {th }}$ to the $15^{\text {th }}$ century. In the region of Vojvodina, this type of pottery was found in Bečej, Vrbas, Čurug, Pećinci and Vrcalova vodenica near Ruma, where it was dated to the period from the $14^{\text {th }}$ to the beginning of the $16^{\text {th }}$ century. ${ }^{26}$ The closest similarities regarding the territory have been discovered among pottery finds in Kovin and Idvor, dated to the $14-15^{\text {th }}$ century. ${ }^{27}$ The same types of vessels have been found in the late medieval deposits in Belgrade, dated between 1427 and $1521 .^{28}$ Similar pottery found on Romanian sites was dated approximately to the same period. ${ }^{29}$ On the other hand, similarities regarding the manufacture of pottery can also be found among the Serbian pottery originating from the $14-15^{\text {th }}$ century. $^{30}$

\footnotetext{
${ }^{26}$ Гачић 1995, 241, T. I/1, 242, T. II/16, 247, T. VII/1; Станојев 1996,44 , сл. 4,59 , сл. $4 / 18,60$, сл. 4/19, 65, сл. 4/25, 72, сл. 4/41, 78, сл. 6; Трифуновић, Пашић 2003,286 , сл. 19/3-4.

27 Зечевић 1997, 196, Т. V/4, 197, Т. VI/12; Ћорђевић, Ђорђевић 2005, 266-267, сл. 8/8, 9/4-5, 9. ${ }^{28}$ Бикић 1994,76, сл. $27 / 2,3,17 ; 77$, сл. $28 ; 78$, сл. $29 / 3 ; 81$, сл. $30 / 1,5,7,8,11 ; 86$, сл. $33 / 2,3,5$.

${ }^{29}$ Spinei 1996, 47, Fig. 3/4,6,7; 48, Fig. 4/1; Crișan 1998, 109, Fig. 3/1,2,5,6; Fig. 4/1,2; 111 , Fig. 5/3.

30 Janković, Janković 1978, 163, sl. 5/1,3,4,6-8; Popović 1978, 108, sl. 3; Bajalović-Hadži-Pešić 1981, 45, T. V/3, 48, VIII/3; Vasić, Ercegović-Pavlović, Minić 1984, Fig. 121/1-3.
} 
The latest phase of life on the northeast part of the site was defined by the partly explored necropolis, buried over the remains of houses 1 and 3 (PI. 3). The explored graves are situated at about $100 \mathrm{~m}$ northeast of the house 2 and they can be roughly placed into the same chronological period and therefore it can be supposed that the necropolis belonged to the same settlement as this house. It was discovered a total number of 8 graves ( 6 in the test surface 1/2003 and in the trench $4 / 2004$ and 2 graves in the test surface 1/2004), of which 7 are complete (Pl. 8). The parts of a skeleton found in the nearby profile of the old excavation on the brick factory ground showed that this necropolis was spreading on quite a larger area than the one included in the excavations.

Skeletons were found at relative depths between $1.20 \mathrm{~m}$ and $1.70 \mathrm{~m}$. Anthropological analysis showed that the deceased in burial No. 8 was about 10 years old boy, the deceased in burials Nos. 3, 5, 9 and 10 were women aged about $25,18-20$ and about 50 , while the deceased in burials Nos. 6 and 7 were men aged about 50 and 50-60. The burials were individual, in simple burial pits of different shapes and sizes (PI. 9/1-4). The female burial No. 3 is rectangular and its dimensions are $1.91 \times 0.75 \mathrm{~m}$, while burial pits with rounded angles, $2.4 \times 0.9 \mathrm{~m}$ and 2.3 $\times 0.9 \mathrm{~m}$ in dimensions, were found in graves Nos. 7 and 9. There are three burial pits with sills made out of earth lining the walls. A rectangular burial pit, $2.3 \mathrm{~m}$ long and $0.95 \mathrm{~m}$ large, with $10-22 \mathrm{~cm}$ large sills lining all four walls was found in the grave No. 6 , while a similarly buried trapezoidal burial pit, $2.15 \mathrm{~m}$ long and $0.43-0.7 \mathrm{~m}$ large, with $6-12 \mathrm{~cm}$ large sills, was found in a female grave No. 5 . A $1.54 \mathrm{~m}$ long oval burial pit, with a $3-18 \mathrm{~cm}$ large sill lining the south, west and north wall, was found in the grave No. 8 .

The graves are oriented in the main direction west-east, with different tolerances in the north direction ranging from $17^{\circ}$ to $40^{\circ}$. The diseased were laid down on their back in a stretched position with the skull lying on the nape. The position of their arms was very diverse, but, according to the graves in which the position of both hands was precisely defined, they were generally crossed or placed on the abdomen and chest. In the graves Nos. 5, 6 and 8 both hands are placed on the abdomen, while in the grave No. 3 one hand is placed on the abdomen and the other on the pelvis, and in the graves Nos. 7 and 9 one hand is placed on the abdomen and the other on the chest.

Grave offerings were discovered in 7 graves and they consist of iron nails, objects used as personal decoration and functional parts of clothes. Iron nails were found in 5 graves (Pl. 25/1-6). In the grave No. 3 were found 3 nails - two above the skull and the third in the filling of the burial pit. Two nails were found during the cleaning of the burial pit in the grave No. 8, while one nail was found in each of the graves Nos. 5 (near the edge of the burial pit), 6 (during the cleaning of the burial pit) and 7 (above the left foot). The appearance of nails is difficult to define precisely and that is why it is not clear whether they come from the structures, coffins used for the burial or they got in the burial pit in some other way. Traces of wood were found only in the grave No. 7 where, above the skull, a part of a wooden board was preserved, as well as a fragment of wood under the right knee.

Rings were found in two graves. On the right hand of the deceased woman buried in the grave No. 9 was found one ring, while the deceased woman in the grave No. 10 had two rings on the left hand. The ring from the grave No. 9 was molten out of bronze, in form of a closed circular loop $1.9 \mathrm{~cm}$ in diameter, which was enlarged to form an ellipsoid head without ornament, $1.4 \times 9 \mathrm{~cm}$ in diameter, with about $4 \mathrm{~mm}$ wide upper side and gradually narrowing towards the lower part up to $2 \mathrm{~mm}$ (Pl. 25/24). The second ring was also made out of bronze and typologically can also be attributed to the group of molten rings with a distinctive ellipsoid head. The head of the ring contains an ornament consisting of parallel incised lines, with two longer slanted lines above them (Pl. 25/25).

Next to the skull of the deceased woman buried in the grave No. 3 there were found 4 bronze needles - pins, about $7 \mathrm{~cm}$ long (PI. 25/10-13). They have circular section and 
they are pointed at one end, while the other end finishes with a small spherical head.

Hollow spherical buttons made out thin bronze plate, $0.7-1 \mathrm{~cm}$ in diameter, with small loops made out of hooked wire used for buttoning in, were found in four graves. In each of the graves Nos. 5 and 10 there were found four buttons on the chests of deceased woman (PI. 25/14-17, 20-23), while in the grave No. 3 were found three samples - one above the shoulder blade on the right of the skull, the second next to the right wrist and the third on the chest (Pl. 25/7-9). One button was found next to the right hand of the deceased woman in the grave No. 9 ( $\mathbf{P l}$. 25/19). Besides simple examples made out of two dome-shaped parts seemed in the middle, in the graves Nos. 5, 9 and 10 there were also found buttons with a pseudo granule on the lower part.

According to the analysis of the grave offerings, the excavated graves can be roughly dated to the $14-16^{\text {th }}$ century. One of the rings from the grave No. 10 belongs to the group of simple wedding rings (PI. 25/24) which, according to its typological characteristics, is not too chronologically sensitive. Similar wedding rings from the necropolis of Novo Brdo were roughly dated to the late Middle Ages and Turkish period. ${ }^{31}$ Simple examples consisting of a loop, dated to the $15-16^{\text {th }}$ century, had already been found in the Fortress of Smederevo, and they originate from the disturbed layers of the necropolis in the southeast corner of Veliki grad. ${ }^{32}$ In the graves of this necropolis were found several finds with emphasized ellipsoid head, similar to those found in the graves Nos. 9 and 10 (Pl. $25 / 18,25)$. They were roughly dated to the $14-15^{\text {th }}$ century. ${ }^{33}$ A similar ring, dated to the $15^{\text {th }}$ century, was found in the village of Udovice in close surroundings of Smederevo. ${ }^{34}$ Such rings were found in the area spreading towards the south up to Novo Brdo, Prilep and Demir Kapija, but they are not characteristic for the region spreading

\footnotetext{
3! Зечевић 2006, 79-82, 178-182.

32 Цуњак, Марковић-Николић 1997, 97-98, сл. 1-2.

33 Цуњак, Марковић-Николић 1997, 75-77, 89, сл. $6 / 1,90$, сл. 7/1, 9/1.

${ }^{34}$ Бајаловић-Хаџи-Пешић 1984, 107, Т. XLV/4.
}

north to the Sava and Danube. ${ }^{35}$ As far as we know, the only similar example in this region, at least regarding the most general similarities as the shape of the loop and the head, could be represented by the incidental find from Botoš. $^{36}$

Bronze needles with spherical head, similar to those found in the grave No. 3 belong to a very common type of needle pin, which represents a usual inventory of the late medieval graves and graves from the later centuries in the territory of Serbia. The use of this type of needle in Novo Brdo was roughly dated to the $14-16^{\text {th }}$ century, while their appearance in the Serbian Danube Basin was dated to a longer period from the $14 / 15^{\text {th }}$ to the $19^{\text {th }}$ century. ${ }^{37}$ Territorially the closest parallels were again found in the mentioned necropolis in the southeast part of Veliki grad on the Fortress of Smederevo (Цуњак и Марковић-Николић 1997: 93, сл. 17/1). On the necropolis Zapodan in Ravne there was discovered a part of tissue with about twenty similar needles representing the remains of an object decorating the head which were used not only as functional, but also as ornamental objects. ${ }^{38}$ At the mouth of the river Porečka there was found a grave dated to the $16^{\text {th }}$ century, with abundantly equipped female skeleton with four spherical headed bronze needles next to the skull. ${ }^{39}$ This type of needle was found on the necropolis of the church in Donja Bela Reka near Bor, in the same grave with pierced coins of the Polish ruler Sigismund I (1506-1548). ${ }^{40}$

Hollow spherical buttons made out of thin bronze plate with a loop on the upper part, similar to the finds from the graves Nos. $3,5,9$ and 10 , represent usual finds on a great number of sites in Serbia and most of them were dated to the $14-16^{\text {th }}$ century, although they appear in the same shape even later, up to the $18^{\text {th }}$ century. ${ }^{41}$ Similar buttons made out of silver plate were found during the

\footnotetext{
35 Зечевић 2006, 197, кат. бр. 73; Манева 1992, Т. 93, $31 / 86,65 / 18$.

${ }^{36}$ Станојев 1989, 30-31, кат. бр. 161.

37 Зечевић 2006, 55-57, нап 115; Ерцеговић-

Павловић 1984, 255, 257.

${ }^{38}$ Томовић 2001, 336-337.

${ }^{39}$ Минић 1984, 295.

${ }^{40}$ Вуксан, Зечевић, Живковић 1988, 152.

41 Зечевић 2006, 119-123, 215-216, тип 1 и тип $2 /$ в.
} 
excavation of the nearby necropolis on the site of Humka - Refinery in Vojlovica and there were also found similar examples in Belgrade and Smederevo. ${ }^{42}$

Although they were rather modest regarding their scope, archaeological excavations carried out in 2003-2004 resulted in discovery of enough closed archaeological complexes according to which it can be stated that on the rest of the site there are still the remains of a long lasting medieval settlement which existed, with several interruptions, from the $10^{\text {th }}$ to the $15-$ $16^{\text {th }}$ century. During the whole period, the settlement kept the same position on the high bank of the marshy terrain, not far from the Tamiš-Danube confluence. Its durability over such a long period of time was due to all the advantages which this place offered in the everyday life, satisfying the most basic needs of the inhabitants. The most important was certainly the presence of water and the fact that the surrounding terrains were appropriate for agriculture and cattle breeding, but also the existence of an important nearby crossing over the Danube and a road which continued towards the north along the Tamiš river.

The life in this settlement was interrupted and renewed several times. The explored houses were abandoned, but not in a rush, since there is no inventory left inside, or traces of destruction of fire. The end of life in the oldest house 3 could be limited to the last decades of the $10^{\text {th }}$ and the beginning of the $11^{\text {th }}$ century. It was a period of turbulent events on both sides of the Danube. On the right bank, that was the time when the state of Samuel was ruined and when Byzantium established its power after the accessing of Vidin in 1002 and the fall of Sirmium in 1018. On the other side, in the region of the present Banat, at the same time there was a conflict between the Hungarian king Stephen I (1000-1038) and the Prince Ahtum who reigned independently over the regions spreading from Kereš to the Danube and from the Tisa to the south Carpathians. There are different opinions regarding the dating of the campaign by which the king Stephen had finally resolved the problem of governance over the eastern parts of the Carpathian basin, therefore it is dated from $1003 / 1004$ to 1028 and even up to $10344^{43}$

The later stage of life in the settlement defined by the house 1 and oven 1 , together with the nearby hearth, was dated to the $12^{\text {th }}$ century and the first half of the $13^{\text {th }}$ century. In that period the South Banat was a border region of the Hungarian Empire, first towards the Byzantium and, after its ruin in the Danube Basin, also towards the renewed state of Bulgaria.

The periods of peace were changing with war destructions which used to strike this region and could have certainly influenced the life in the settlement on the site Najeva ciglana. The last event which could have caused the end of life at this stage could have been a great Mongol invasion which happened in these regions in 1241-1242.

The latest level of the settlement was defined by the house 2 which can be roughly dated from the $14^{\text {th }}$ to the early $16^{\text {th }}$ century. As far as the south regions of the medieval Hungarian Empire are concerned, that was a dramatic period which started with the entrance of Turks in the Danube Basin, after the battle of Kosovo in 1389. The next century and a half was marked by attempts of the Hungarian Empire to resist to the invader and the main direction of Turkish spreading towards the north went exactly through the part of the Danube Basin spreading from Belgrade to Golubac and representing the location of the greatest conflicts of that time. ${ }^{44}$ During one of the numerous conflicts of that time, the settlement on Najeva ciglana could have been abandoned and it could have lasted not longer than until Turkish invasions over the Sava and Danube which ended by establishment of Temišvar Eyalet in 1552.

\footnotetext{
${ }^{42}$ Станојев 1989, 38-39, кат. 6р. 202-203; БајаловићБирташевић 1960, 32, Т. VIII/11, XII/7, XV/1, 10-12; Цуњак, Марковић-Николи 1997, 78-79, 81-82; 91, сл. $10 / 1$; 95 , сл. $23 / 1,24 / 1,25 / 1,26 / 1$; 96, сл. $27 / 1$, $28 / 1$.
}

\footnotetext{
${ }^{43}$ Madgearu 1983, 5-8.

${ }^{44}$ Калиһ 1983, 109-127.
} 
BIBLIOGRAPHY

Бајаловић-Бирташевић 1960

\section{Bajalović-Hadži-Pešić \\ 1981}

Бајаловић-Хаџи-Пешић
1984

Батистић-Попадић 1988

Бикић 1994

Vasić, Ercegović-Pavlović, Minić 1984

Вуксан, Зечевић, Живковић 1998

Гачић 1995

Ђорђевић 2000

Ђорђевић 2002

Ђорђевић 2007

Ђорђевић 2010

Ђорђевић 2009

Ђорђевић, Ђорђевић 2005

Ђорђевић, Ђорђевић 2009

Ђорђевић, Ђорђевић, Радичевић 2008

Đorđević, Đorđević, Radičević 2005

Ерцеговић-Павловић 1984
М. Бајаловић-Бирташевић, Средњовековна некропола у Мuрuјеву, Београд, 1960.

M. Bajalović-Hadži-Pešić, Keramika u srednjovekovnoj Srbiji, Beograd, 1981.

М. Бајаловић-Хаџи-Пешић, Накит VIII-XVIII века у Музеју града Београда, Београд, 1984.

Д. Батистић-Попадић, Долово-Циглана на делиблатском путусредњовековни слој, Гласник Народног музеја Панчево, 1, 1988, 7-18.

В. Бикић, Средњовековна керамика Београда, Београд, 1994.

R. Vasić, S. Ercegović-Pavlović, D. Minić, Velesnica, prospection par sondage de 1980, Бердапске свеске, 2, Београд, 1984, 129-132.

М. Вуксан, Е. Зечевић, Ј. Живковић, Истраживања на локалитету „Црквина“ код Доње Беле Реке у близини Бора, Гласник Српског археолошког друитва, 14, 1998, 149-153.

Ђ. Гачић, Средњовековна налазишта, in 3. Bana (ур.), Археолошка истражсивања дуж аутопута кроз Срем, Нови Сад, 1995, 233-247.

В.Ђорђевић, Подаци о грнчарији IX-XI века из \&gt; области Вршца, Гласник музеја, Баната, 9/10, 2000, 19-63.

В. Ђорђевић, Рекогносцирање леве обале Тамиша од Баранде до Опова, Гласник музеја Баната, 2002, 11-12, 139-146.

В. Ђорђевић, Сондажно истраживање локалитета Доњоварошка (Најева) циглана у Панчеву 2003. године, Археолочки преглед 1 (2003), 50-54.

В. Ђорђевић, Археолошка налазишта и налази средњовековног периода на територији југозападног Баната (магистарска теза одбрањена на Филозофском факултету Универзитета у Београду, у рукопису).

Ј. Ђорђевић, Средњовековна кућа са локалитета Доњоварошка циглана код Панчева, Гласник музеја Баната, 13/14, 2009, 7-14.

J. Ђорђевић, В. Ђорђевић, Резултати археолошких истраживања вишеслојног локалитета Старо село у Идвору 2002-2004. године, Гласник Српског археолошког друитва, 21, 2005, 251-280.

J. Ђорђевић, В. Ђорђевић, Резултати археолошких истраживања локалитета Старчево - Ливаде 2008. године, Српско археолошко друитво, ХХХІІ Годишњи скуп, 5-7. јун 2009. године Зрењанин (сажетак усменог саопштења), 2009, 27-28.

J. Ђорђевић, В. Ђорђевић, Д. Радичевић, Археолошка истраживања Доњоварошке цитлане у Панчеву у 2004. години, Археолоики преглед, 2/3 (2004/5), 2008, 88-90.

V. Đorđević, J. Đorđević, D. Radičević, New medieval archaeological researches in the region of Pančevo, Banatica, 17, 2005, 261-273.

С. Ерцеговић-Павловић, Равна, средњовековно насеље и некропола, Старинар, 33-34 (1982-1983), 1984, 253-259. 
Žeravica 1974

Зечевић 1997

Зечевић 2006

Јанковић 1981

Јанковић 1983

Јанковић 1995-1996

Јанковић 1997

Janković, Janković 1978

Јанковић,

Јанковић 1990

Janković, Radičević 2005

Калић 1983

Madgearu 1983

Манева 1992

Мано-Зиси et alii 1948

Манојловић 1989

Milleker 1897

Minić 1980

Минић 1984

Haђ 1956

Popović 1978

Поповић,

Иванишевић 1988

Пашић 2001

\section{Spinei 1996}

Станојев 1989

Станојев 1996

Станојевић 1980
Z. Žeravica, Die Keramik des XI und XII Jahrhunderts aus der Ansiedlung in Popovica in der Negotiner Gegend und das Problem ihrer ethnischen Zuteilung den Slawen, Balcanoslavica, 3, 1974, 121-159.

Е. Зечевић, Преглед керамичког материјала са локалитета „Град“ у Ковину, Рад Музеја Војводине, 39, 1997, 185-197.

Е. Зечевић, Накит Новог Брда, Београд, 2006.

М. Јанковић, Средњовековно насеље на Великом Градиу у X-XI веку, Београд, 1981.

М. Јанковић Средњовековни укоп на Малом Калемегдану, Годиињак град Београда, 30, 1983, 9-20.

М. Јанковић, Словенско насеље код Земуна, Рад Музеја Војводине, 37-38, 1995-1996, 123-137.

М. Јанковић, Београд и његова околина од IX до XI века, in В.В. Седов (ред), Труды VI Международного Конгресса славянской археологии, том 1. Проблеми славянской археологии, Москва, $1997,42-52$.

M. Janković, Đ. Janković, Communication sur les recherches auterieures dans la ville Višesav pres de Tekija, Balcanoslavica, 7 , $1978,155-167$.

М. Јанковић, Ћ. Јанковић, Словени у југословенском Подунављу, каталог изложбе, Београд, 1990.

Dj. Janković, D. Radičević, The stronghold from Dupljaja. A medieval archaeological discovery, Banatica, 17, 2005, 275-278.

J. Калић, Дунав у ратовима XV века, in Пловидба на дунаву и ьеговим притокама кроз векове, ур. В. Чубриловић, Београд, 1983, 109-127.

A. Madgearu, Contribuţi privind conflictului dintre ducele Bănăţean Ahtum şi regele Ştefan I al Ungariei, Banatica, 12/II, 1983, 5-8.

Е. Манева, Средновековне накит од Македонија, Скопје, 1992.

Ђ. Мано Зиси, М. Љубинковић, М. Гарашанин, Ј. Ковачевић, Р. Веселиновић, Заштитно ископавање код Панчева, Музеји, Београд, 1, 1948, 53-95.

В. Манојловић, Средњовековни укоп на локалитету Опово-Бели брег, Гласник Народног музеја Панчево, 2, 1989, 41-46.

B. Milleker, Délmagyarország régiségleletei a Honfoglás elötti idökböl I, Temesvár, 1897.

D. Minić, Le site d'habitation medieval de Mačvanska Mitrovica, Sirmium, 11, 1980, Beograd.

D. Минић, Поречка река, средњовековно насеље и некропола, Старинар, 33-34, 1984, 293-295.

Ш. Нађ, Словенске посуде из Чортановаца, Рад војвођанских музеја, 5, 1956, 163-169.

M. Popović, La residence du despote Đurađ Branković dans le chatelet de la forteresse de Smederevo, Balcanoslavica, 7, 1978, $101-112$.

М. Поповић, В. Иванишевић, Град Браничево у средњем веку, Старинар, 39, 1988, 125-179.

И. Пашић, О датовању грнчарије 12-13. века из вршачких радионица, Гласник Сроског археолочког друштва, 17, 2001, 177-194.

V. Spinei, Generalitãti privind geneza orașelor medievale din Moldova, Arheologia medievala, 1, 1996, 35-54.

Н. Станојев, Некрополе X-XV века у Војводини, Нови Сад, 1989.

Н. Станојев, Средњовековна насеља у Војводини, Нови Сад, 1996.

Н. Станојевић, Заштитно ископавање локалитета Ботра код Бечеја-средњовековна лончарска радионица. Подаци о 
Станојевић 1986-1987

Takács 1986

Țeicu, Lazarovici 1996

Томовић 2001

Трифуновић 1989-1990

Трифуновић,

Пашић 2003

Uzum 1977

Uzum 1983

Crişan 1998

Цуњак, МарковићНиколић 1997 локалитету и резултати ископавања, Рад Војвођанског музеја, 26, 1980, 89-119.

Н. Станојевић, Насеља VIII-IX века у Војводини, Рад Војвођанског музеја, 30, 1986-1987, 119-146.

M. Takács, Die arpadenzeitlichen Tonkessel in Karpatenbecken, Varia Archaeologica Hungarica I, Budapest, 1986.

D. Țeicu, G. Lazarovici, Gornea. Din arheologia unui sat medieval din Clisura Dunarii, Oradea, 1996.

М. Томовић, Равна (Campsa) у средњем веку, Зборник Народног музеја, 17/1 (археологија), 2001, 309-340.

С. Трифуновић, Античка и средњовековна археолошка налазишта општине Алибунар, Рад војвођанских музеја, 32, 1989-1990, 99-130.

С. Трифуновић, И. Пашић, „Стари Виногради“ у Чуругу вишеслојно археолошко налазиште, Гласник Српског археолошког друитва, 19, 2003, 263-290.

1. Uzum, Locuirea feudală timpurie de la Gornea-Tărmuri, Banatica, 4, 1977, 215-222.

I. Uzum, Locuirile medievale româneşti de la Gornea-Zomoniţe, Banatica, 7, 1983, 249-298.

I. Crişan, O locuinţă din secolul al XVI-lea din aşezarea medievală Rădvani (jud. Bihor), Arheologia Medievală, 2, 1998, 103-112.

М. Цуњак, Љ. Марковић-Николић, Античке и средњовековне некрополе Смедерева, Смедерево, 1997.

\section{LIST OF PLATES}

PI. 1 - Location map of the site Najeva ciglana in Pančevo (scale 1:50 000).

PI. 2 - Najeva ciglana, site plan with excavated areas.

Pl. 3 - Najeva ciglana, plan of the archaeological finds.

PI. 4-1. Oven (plan and cross-sections); 2. Oven 1, eastern view.

Pl. 5-1. House 1 (plan and cross-sections); 2. House 1, eastern view.

PI. 6 - 1. House 2 (plan and cross-sections); 2. House 2, south-eastern view.

PI. 7 - 1. House 3 (plan and cross-sections); 2. House 2, north-eastern view.

Pl. 8 - 1. Najeva ciglana - plan of the necropolis.

Pl. 9 - 1. Grave No. 6, westem view; 2. Grave No. 7, south-western view; 3. Grave No. 8, western view; 4. Grave No. 9, western view.

Pl. 10 - House 3 - pottery from the filling.

Pl. 11 - House 3 - pottery from the filling, from the floor of the house and the hearth area.

Pl. 12 - Pottery from the layer around oven 1.

Pl. 13 - Pottery from the layer around oven 1.

Pl. 14 - House 1 - pottery from the filling and the bigger hearth area.

Pl. 15 - House 1 - pottery from the filling.

Pl. 16 - House 1 - pottery from the filling.

Pl. 17 - House 1 - pottery from the filling.

Pl. 18 - House 1 - pottery from the floor and the hearth area.

PI. 19 - House 1 - pottery from the floor and the hearth area.

Pl. 20 - House $1-1$. bone plating of a knife; 2-3. unidentified iron objects; 4. clay spindlewhorl.

PI. 21 - Pottery from the leyer around house 2.

PI. 22 - Pottery from the leyer around house 2.

PI. 23 - House 2, pottery from the lowest layer of the filling and from the floor.

Pl. 24 - House 2 - 1, 6-7. tools; 2-5. nails; 8-10. Knives;11. spindle-whorl; 12-13. glass pearls; 14. grindstone.

Pl. 25 - Necropolis, grave offerings. 


\section{LISTA ILUSTRAȚIEI}

PI. 1 - Harta cu localizarea sitului „Najeva ciglana” de la Pančevo (scale 1:50 000).

Pl. 2 - „Najeva ciglana” — planul sitului cu zona cercetată.

PI. 3 - „Najeva ciglana" - planul descoperirilor arheologice.

PI. 4 - 1. Cuptorul nr. 1 (plan şi secțiune); 2. Cuptorul nr. 1 (vedere dinspre est).

PI. 5 - 1. Casa nr. 1, (plan și secțiune); 2. Casa nr. 1, (vedere dinspre est).

Pl. 6 - 1. Casa nr. 2, (plan și secțiune); 2. Casa nr. 2, (vedere dinspre sud-est).

Pl. 7 - 1. Casa nr. 3, (plan și secțiune); 2. Casa nr. 2, (vedere dinspre nord-est).

PI. 8 - „Najeva ciglana” - planul necropolei.

PI. 9 - 1. Mormântul nr. 6 (vedere dinspre vest); 2. Mormântul nr. 7 (vedere dinspre sud-vest); 3. Mormântul nr. 8 (vedere dinspre vest); 4. Mormântul nr. 9 (vedere dinspre vest).

PI. 10 - Casa nr. 3 - ceramică din umplutură.

Pl. 11 - Casa nr. 3 - ceramică din umplutură, de pe podeaua casei şi din zona vetrei.

Pl. 12 - Ceramică de pe nivelul din jurul cuptorului nr. 1.

Pl. 13 - Ceramică de pe nivelul din jurul cuptorului nr. 1.

P1. 14 - Casa nr. 1 - ceramică din umplutură și din zona vetrei mari.

Pl. 15 - Casa nr. 1 - ceramică din umplutură.

PI. 16 - Casa nr. 1 - ceramică din umplutură.

Pl. 17 - Casa nr. 1 - ceramică din umplutură.

Pl. 18 - Casa nr. 1 - ceramică de pe podea şi din zona vetrei.

PI. 19 - Casa nr. 1 - ceramică de pe podea şi din zona vetrei.

PI. 20 - Casa nr. 1 - 1. plăsea din os pentru cuţit; 2-3. Obiecte din fier neidentificate; 4. fusaiolă din lut.

Pl. 21 - Ceramică de pe nivelul din jurul casei nr. 2.

PI. 22 - Ceramică de pe nivelul din jurul casei nr. 2.

PI. 23 - Casa nr. 2 - ceramică de pe nivelul inferior al umpluturii și de pe podea.

PI. 24 - Casa nr. 2- 1, 6-7. unelte; 2-5. cuie; 8-10. cuţite; 11. Fusaiolă; 12-13. Mărgele din sticlă; 14. şlefuitor.

Pl. 25 - Necropola - inventarul mormintelor.

\section{Dejan RADIČEVIĆ}

Department of Archaeology, Faculty of Philosophy University of Belgrade dradicev@f.bg.ac.rs Vojislav ĐORĐEVIĆ National Museum Pančevo djordjevic.vojislav1@gmail.com Jelena ĐORĐEVIĆ

National Museum Pančevo jelenadjordjevic2009@hotmail.com 


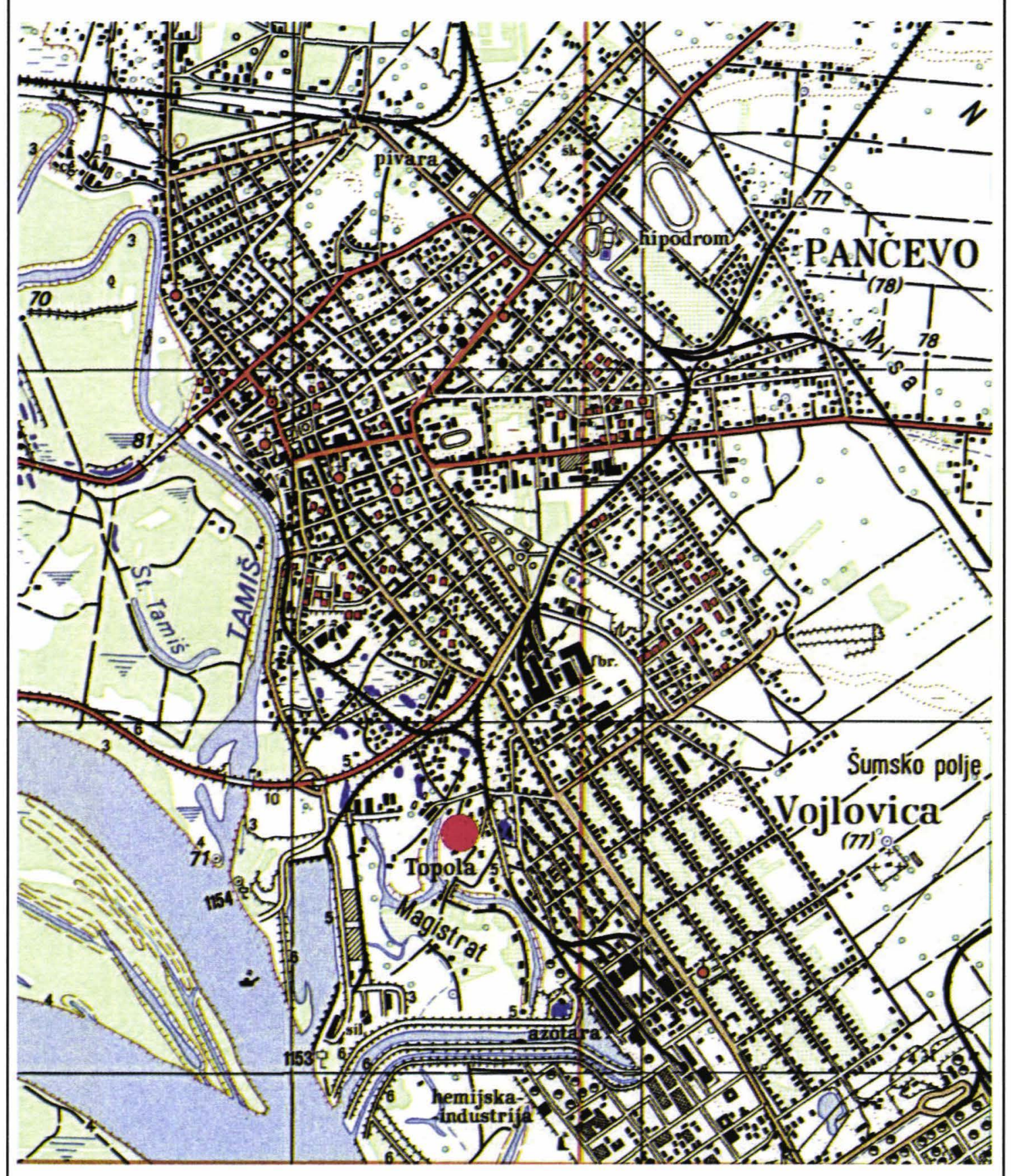

PI. 1 - Location map of the site Najeva ciglana in Pančevo (scale 1:50 000). 


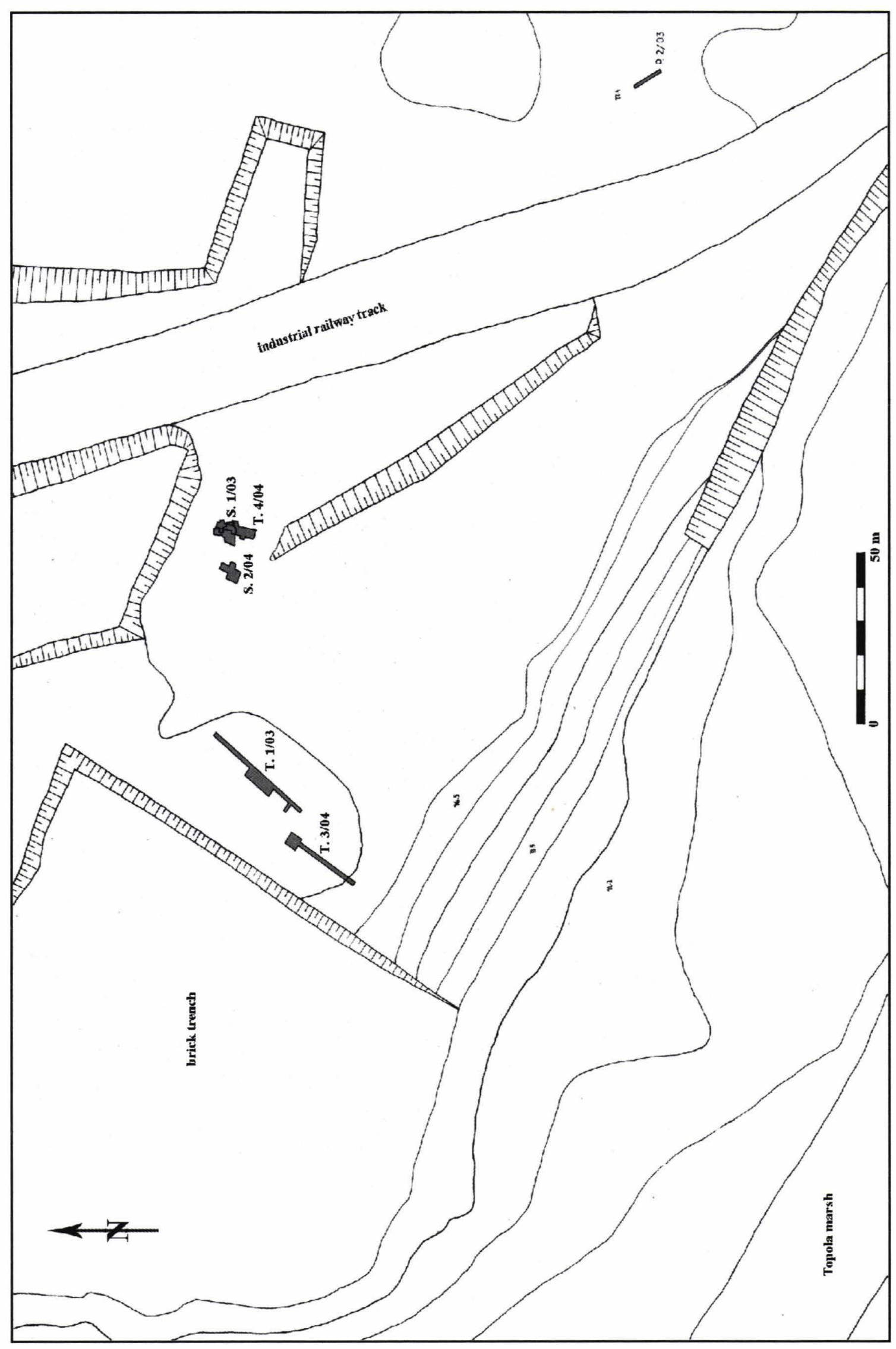

PI. 2 - Najeva ciglana, site plan with excavated areas. 


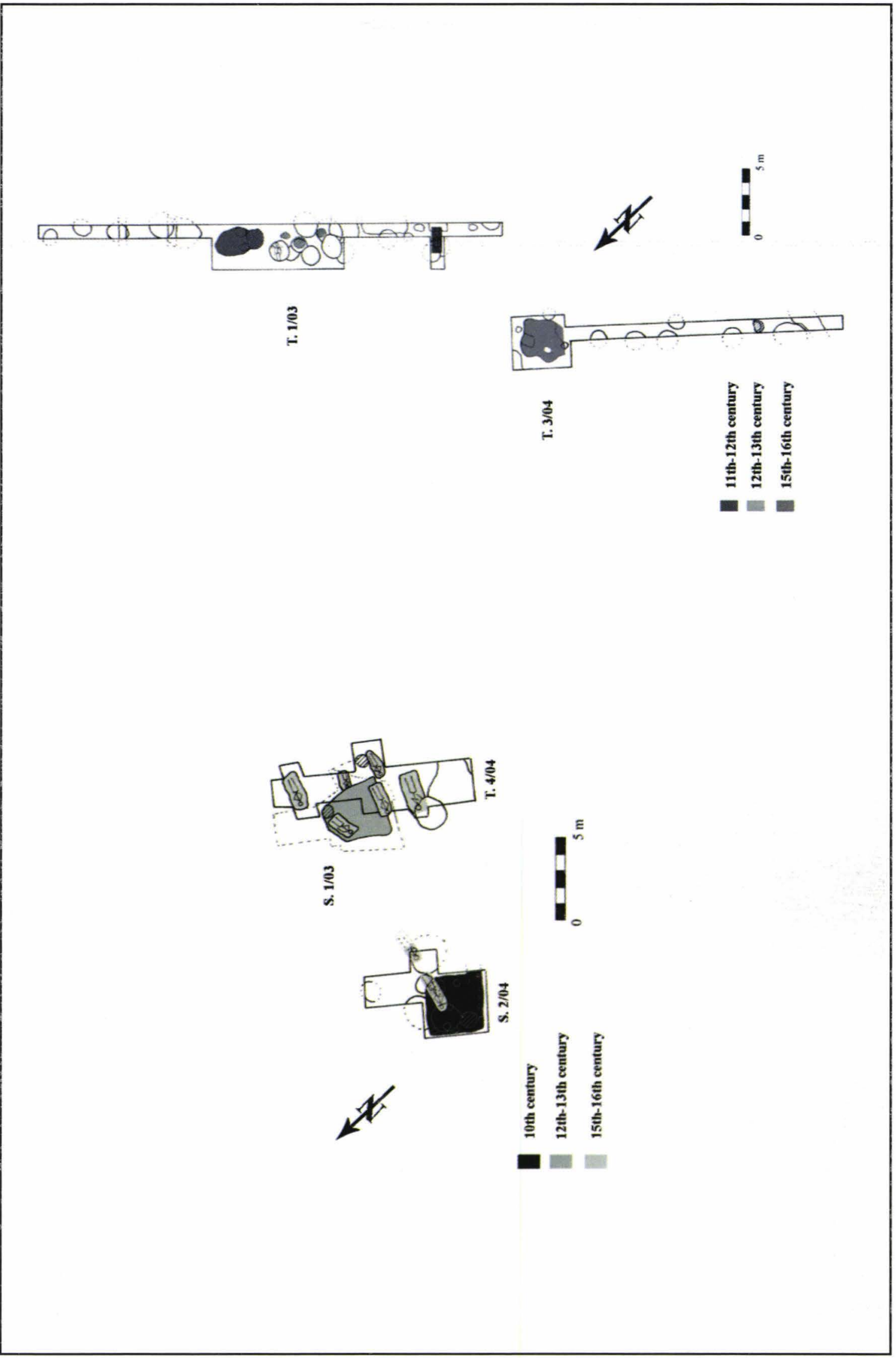

PI. 3 - Najeva ciglana, plan of the archaeological finds. 


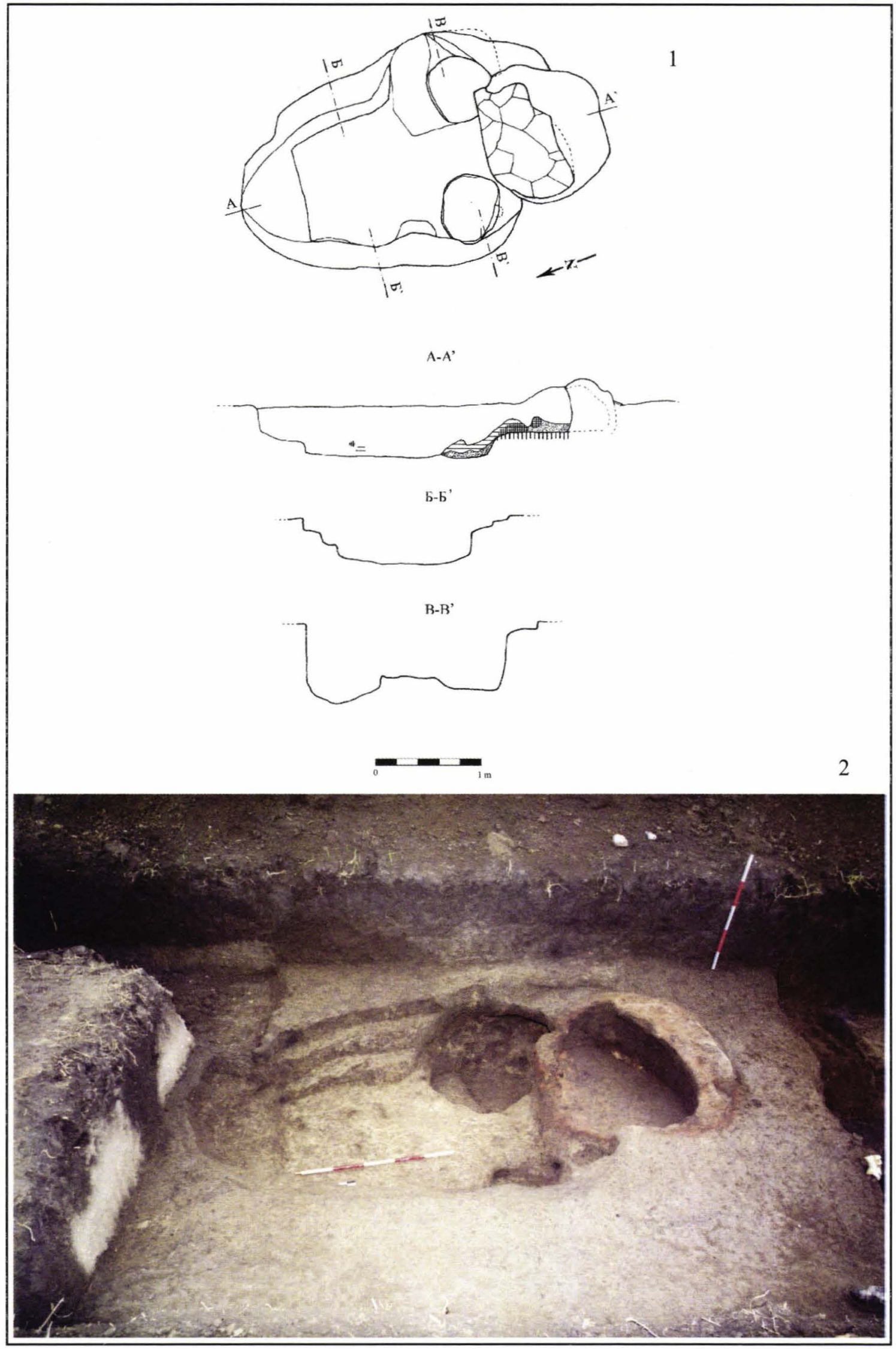

PI. 4 - 1. Oven (plan and cross-sections); 2. Oven 1, eastern view. 


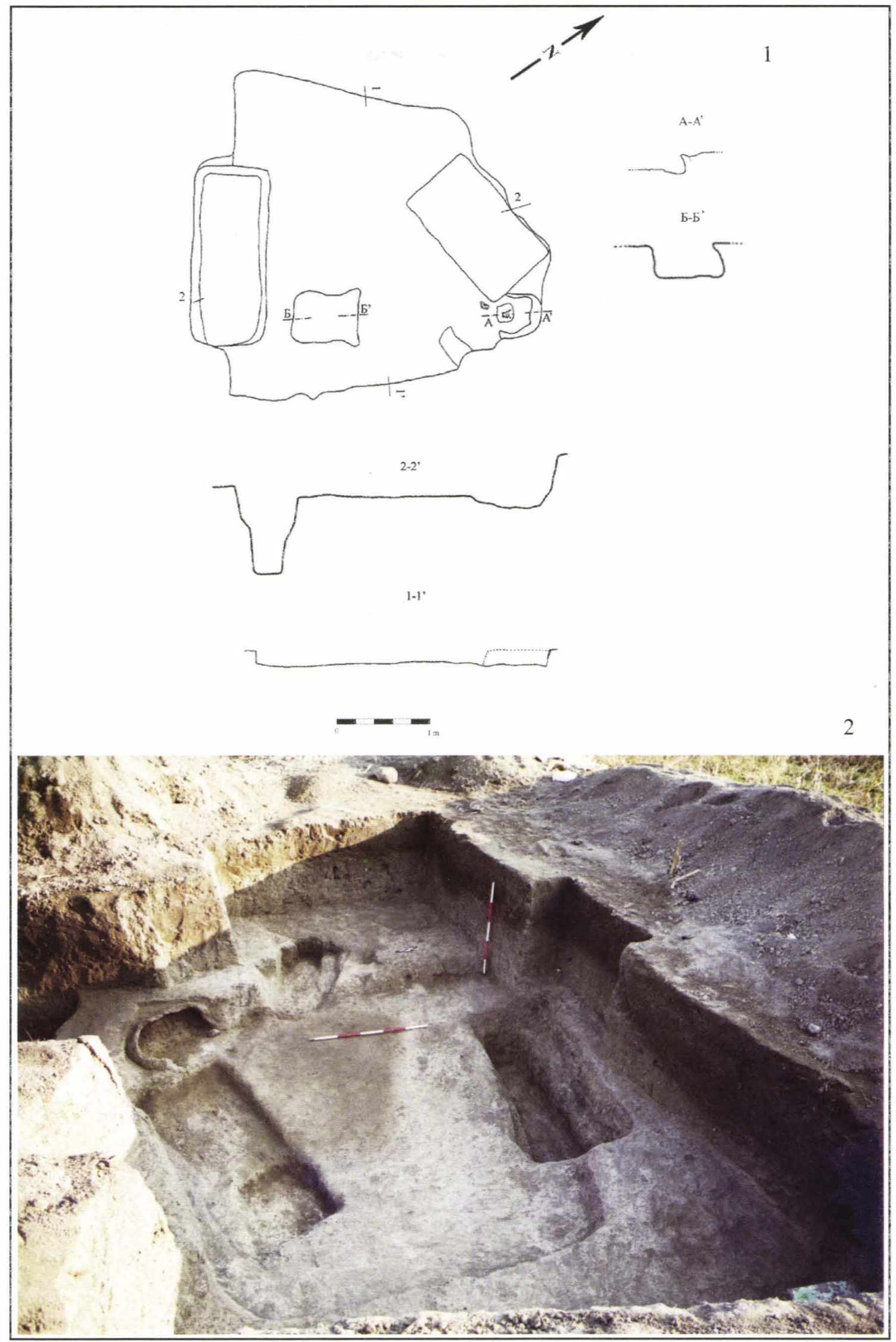

Pl. 5 - 1. House 1 (plan and cross-sections); 2. House 1, eastern view. 


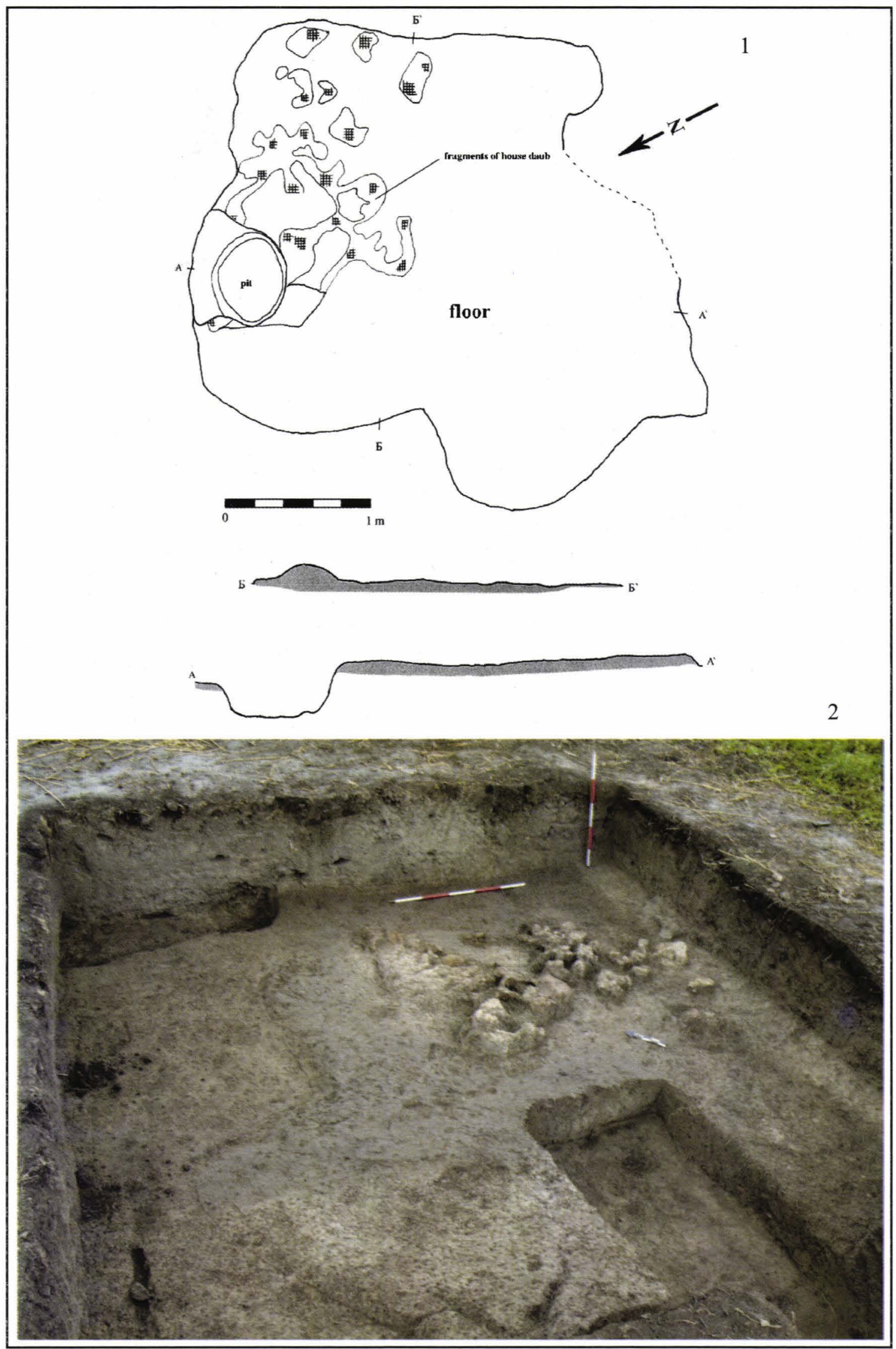

Pl. 6 - 1. House 2 (plan and cross-sections); 2. House 2, south-eastern view. 


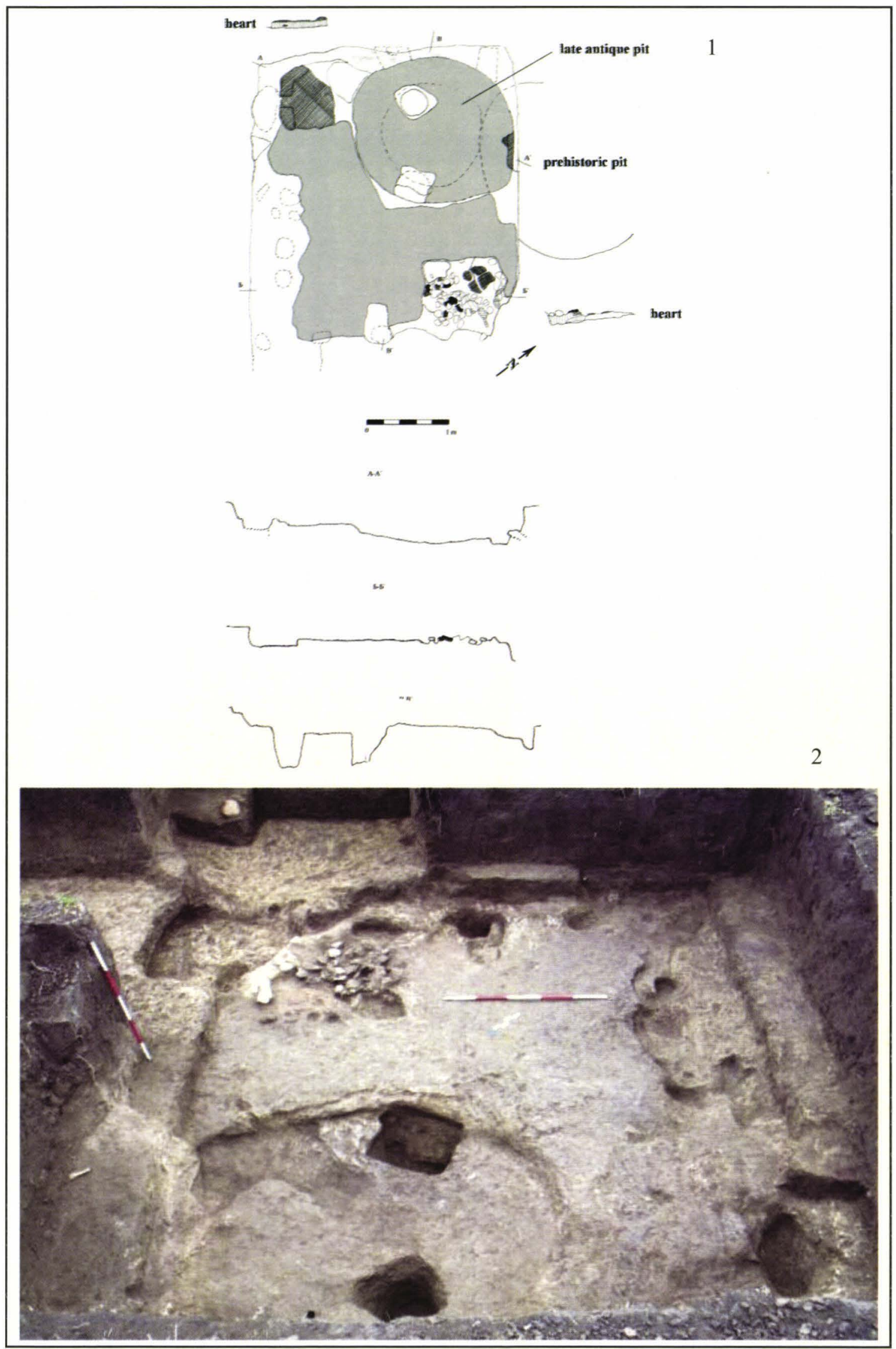

PI. 7 - 1. House 3 (plan and cross-sections); 2. House 2, north-eastern view. 


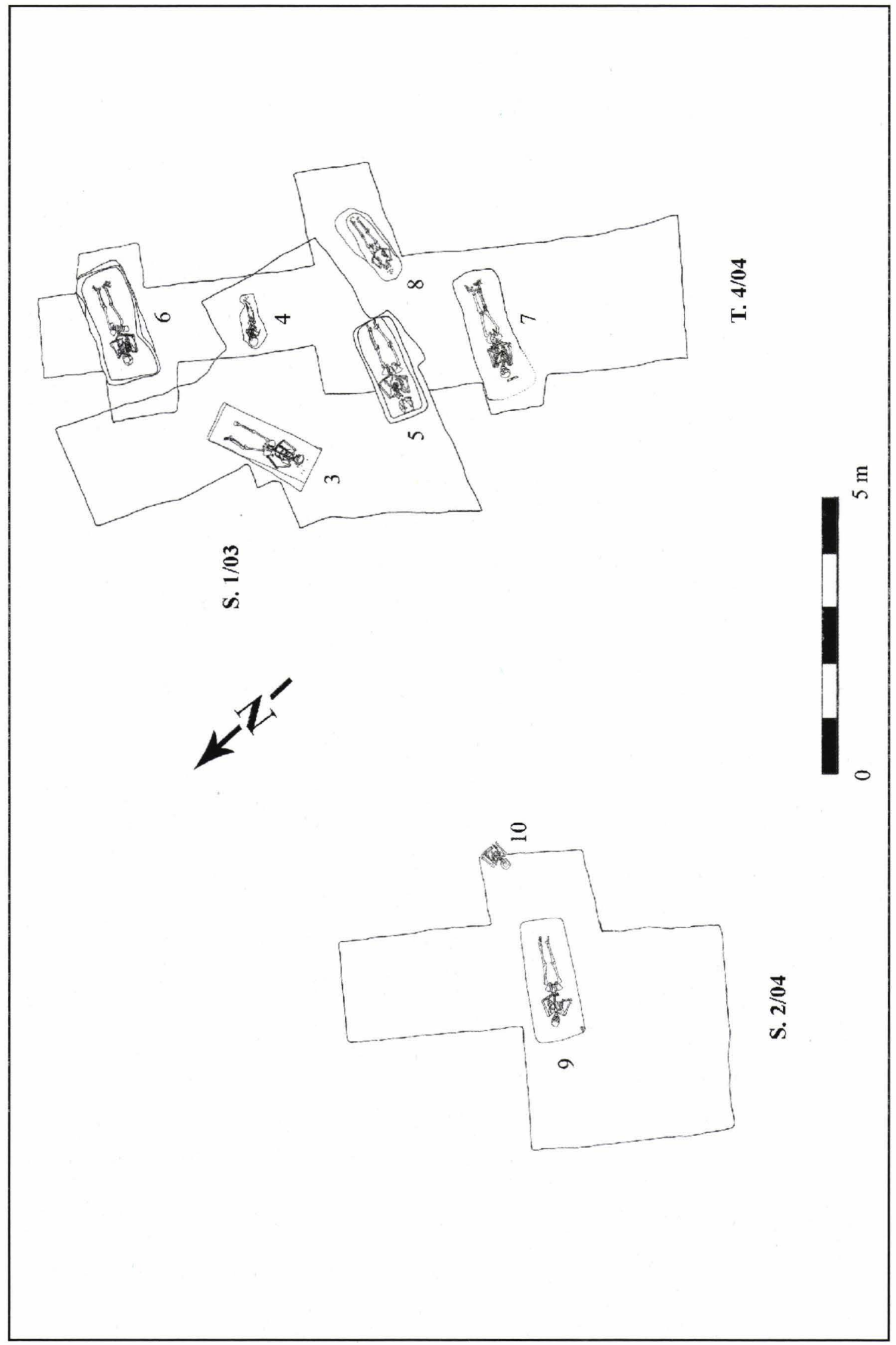

PI. 8 - 1. Najeva ciglana - plan of the necropolis. 


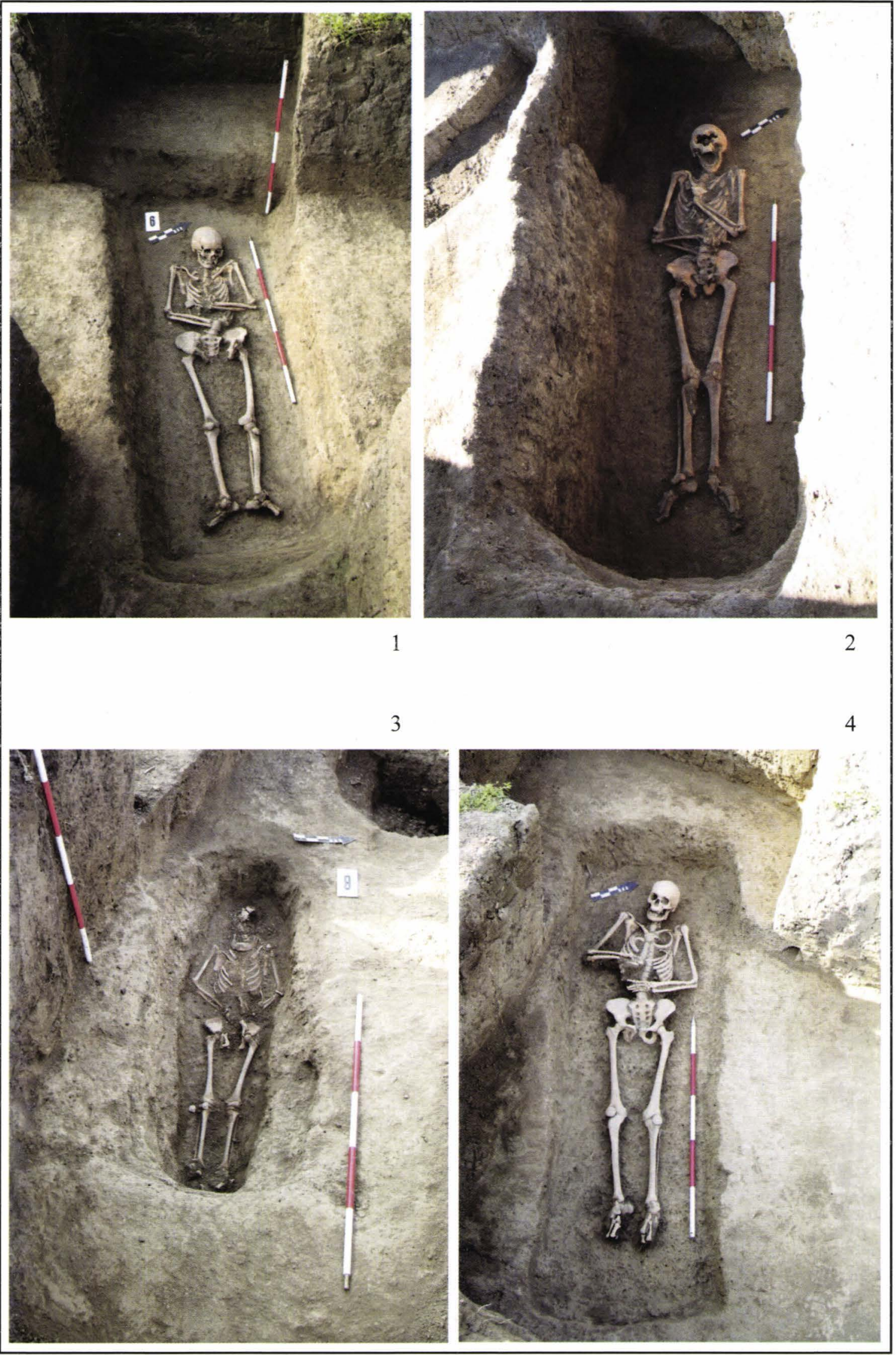

PI. 9 - 1. Grave No. 6, western view; 2. Grave No. 7, south-western view; 3. Grave No. 8, western view; 4. Grave No. 9, western view. 

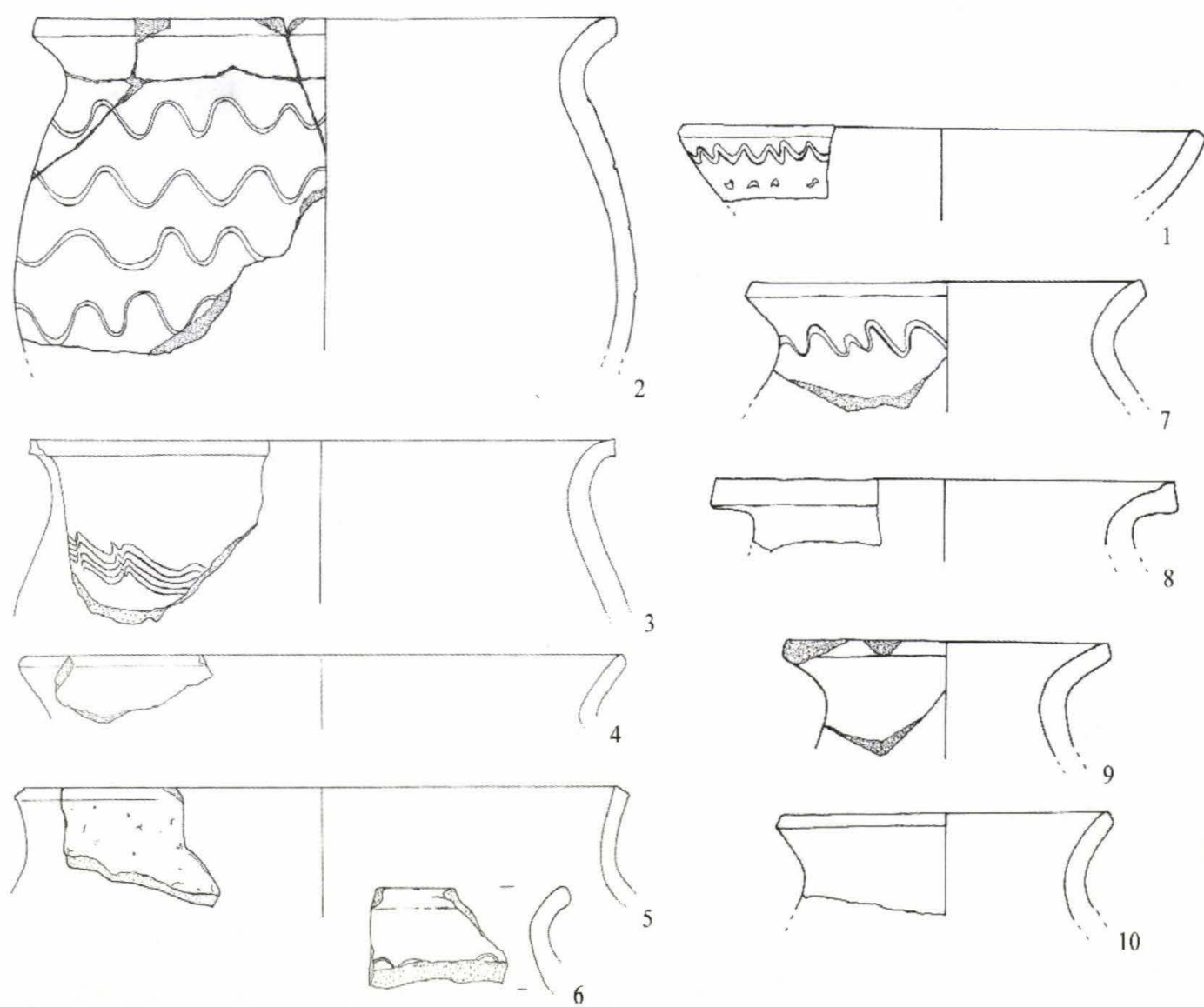

$-2-5 \mathrm{~cm}$
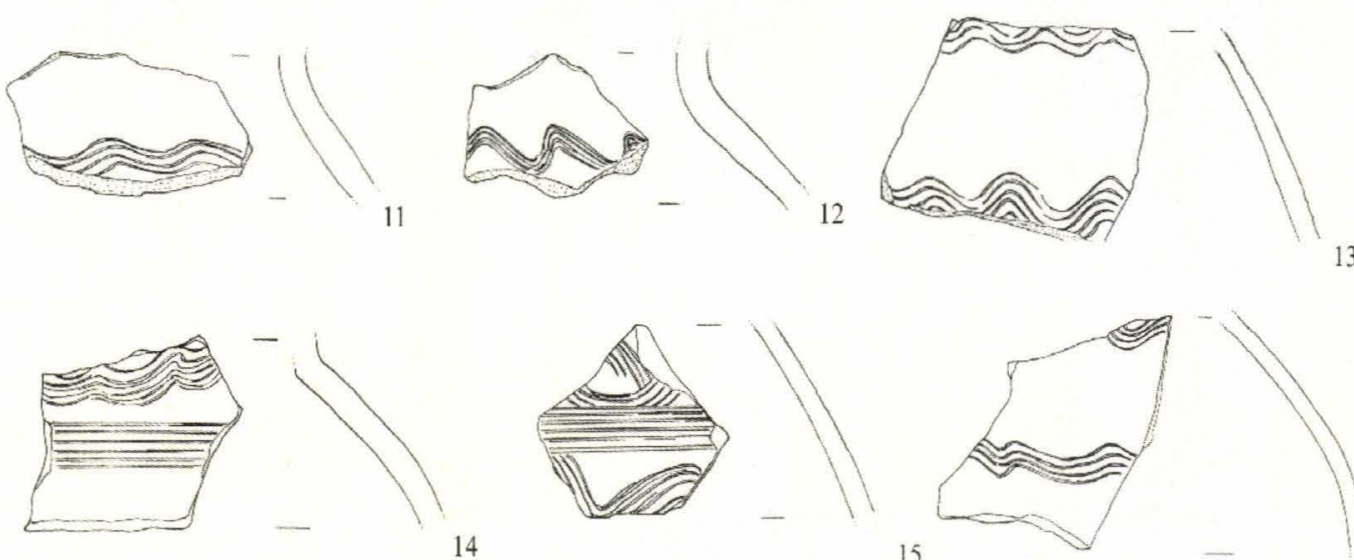

14
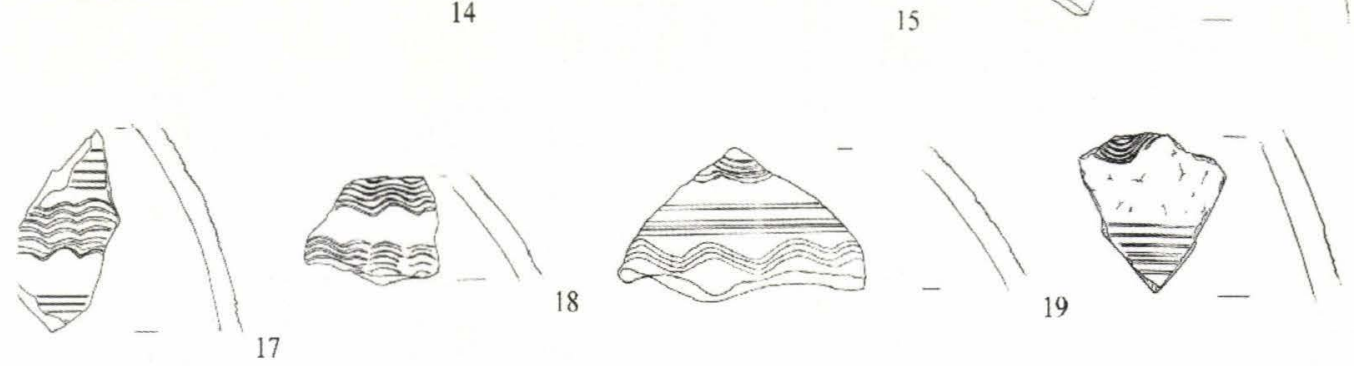

PI. 10 - House 3 - pottery from the filling. 

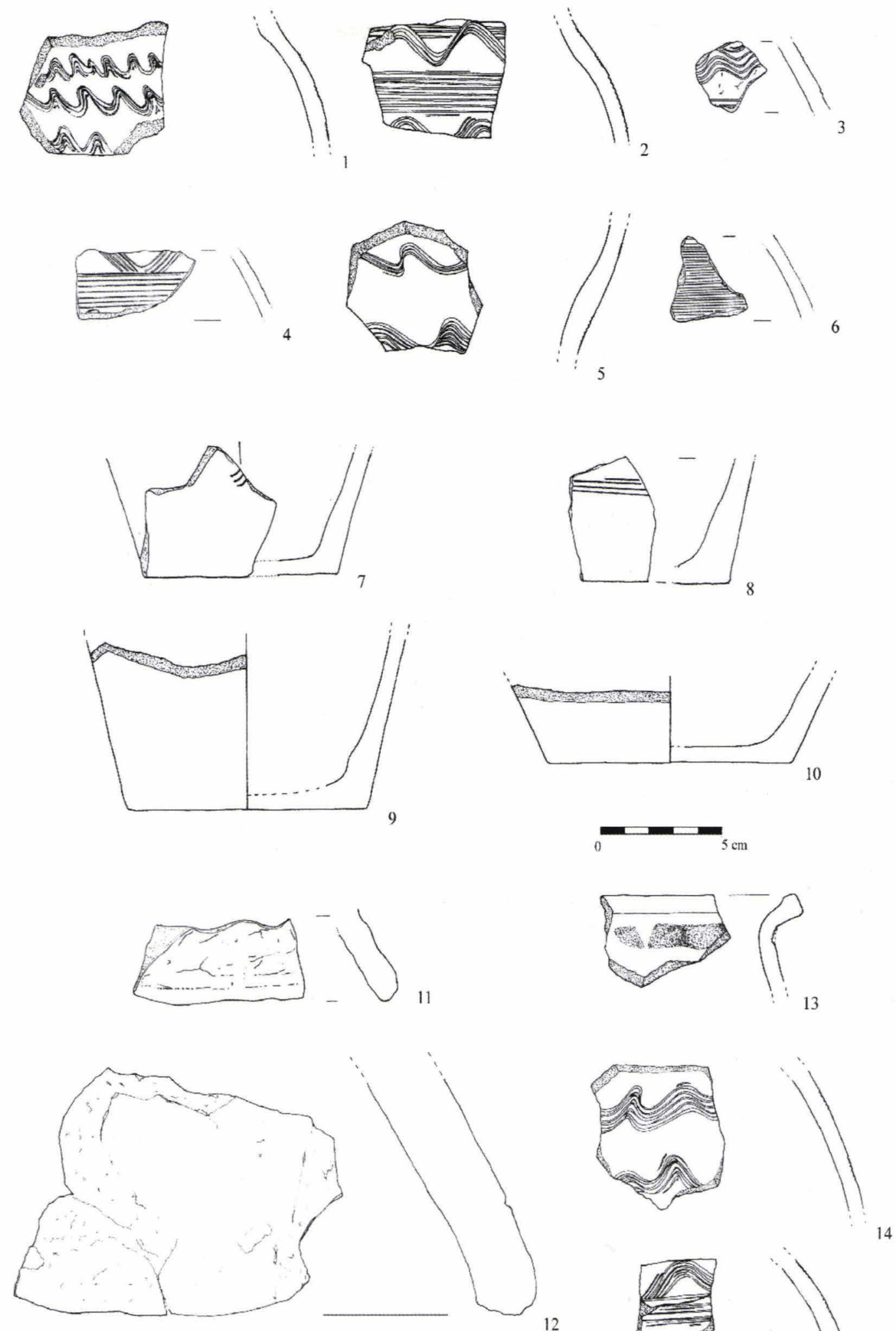

12
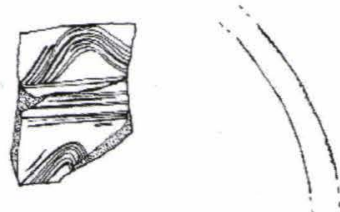

Pl. 11 - House 3 - pottery from the filling, from the floor of the house and the hearth area. 

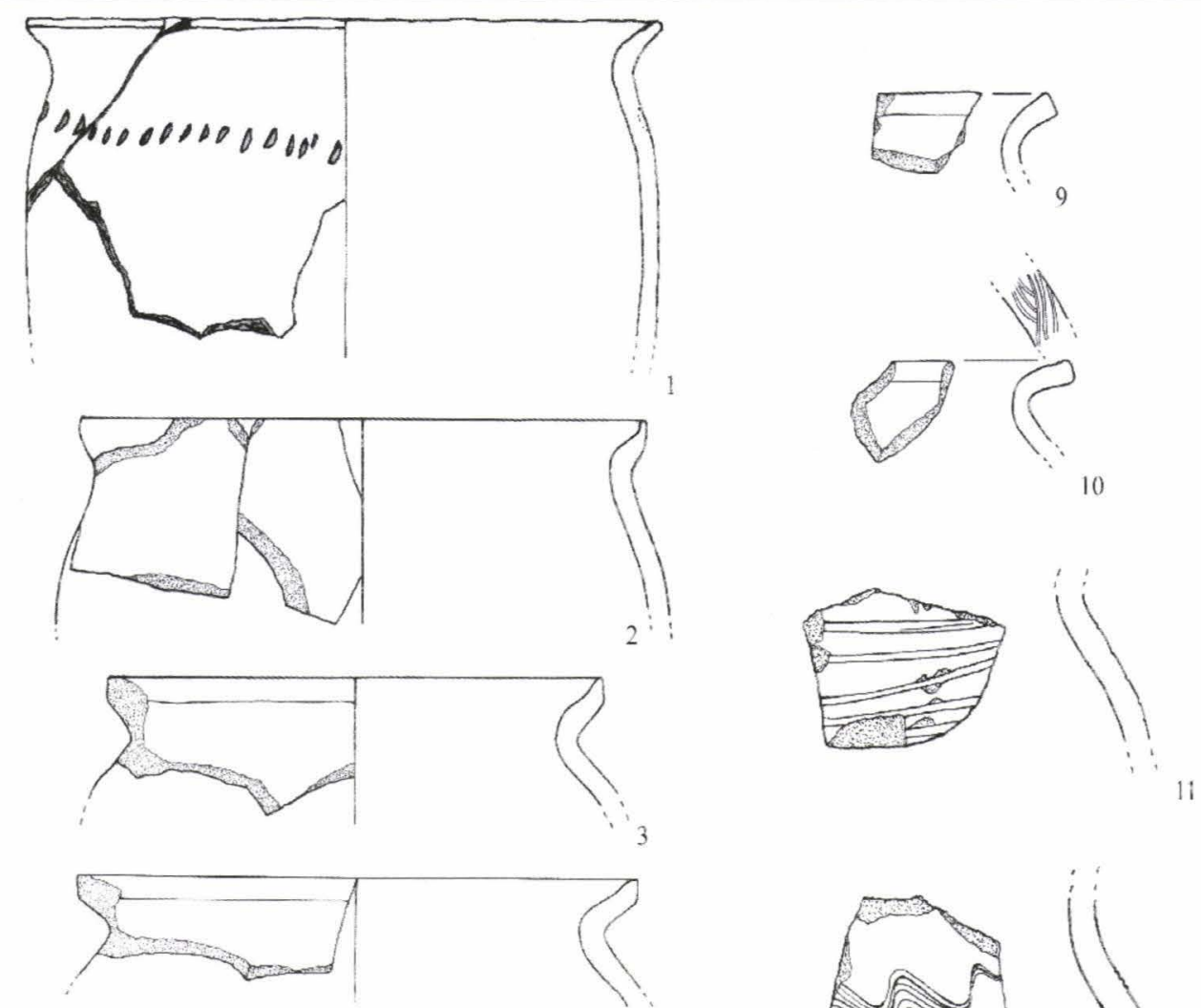

4
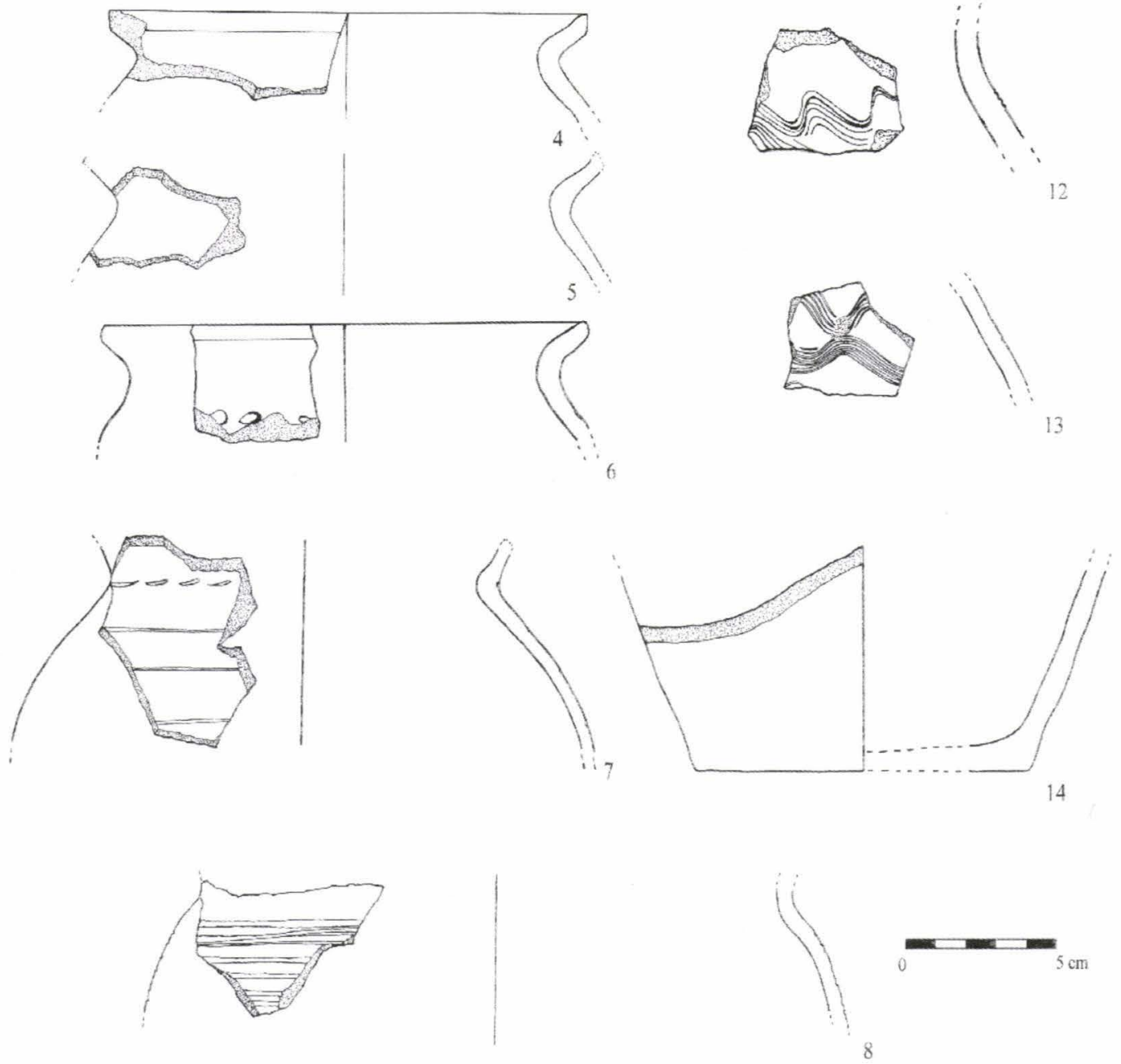

Pl. 12 - Pottery from the layer around oven 1. 


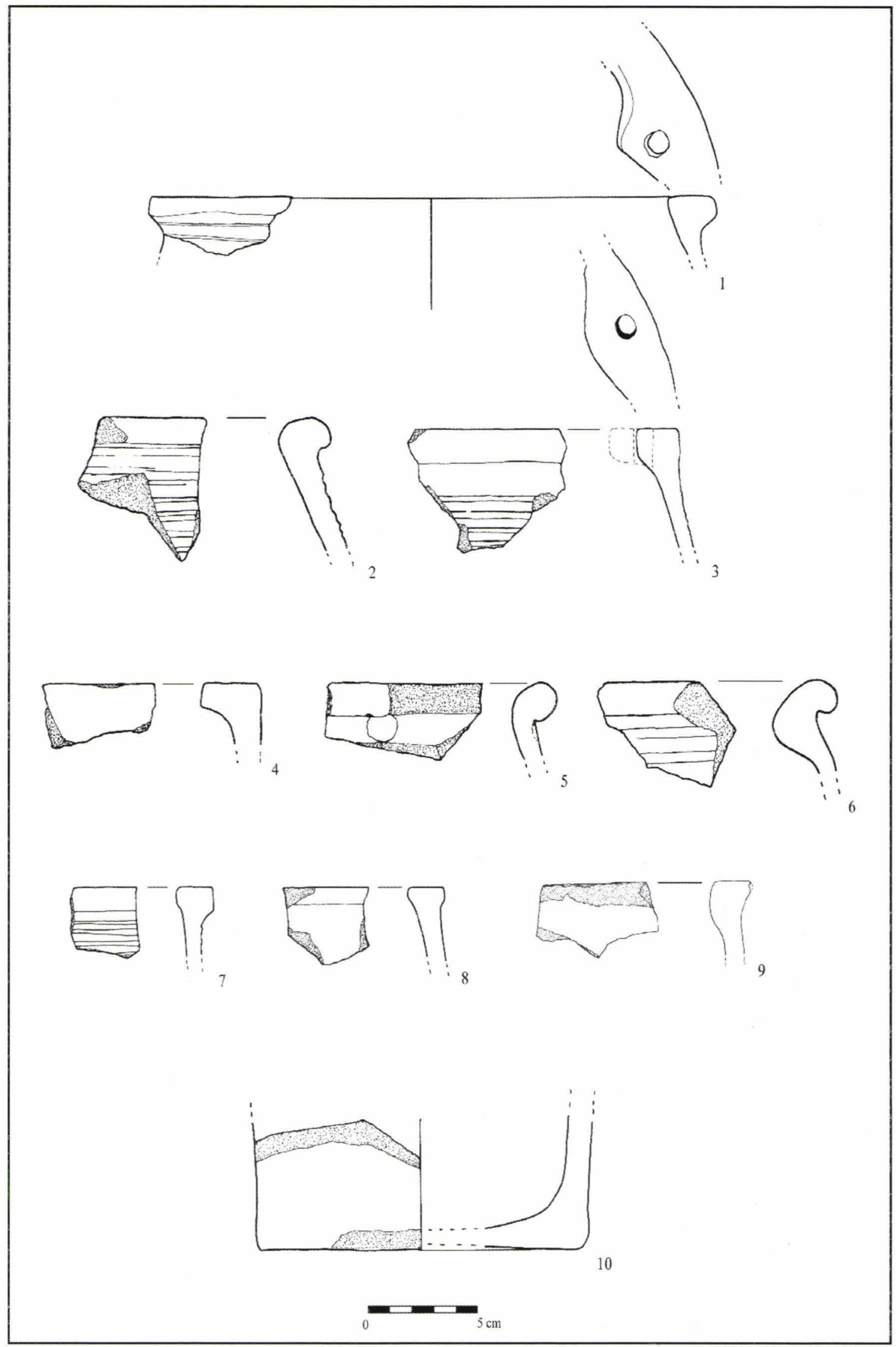

PI. 13 - Pottery from the layer around oven 1. 

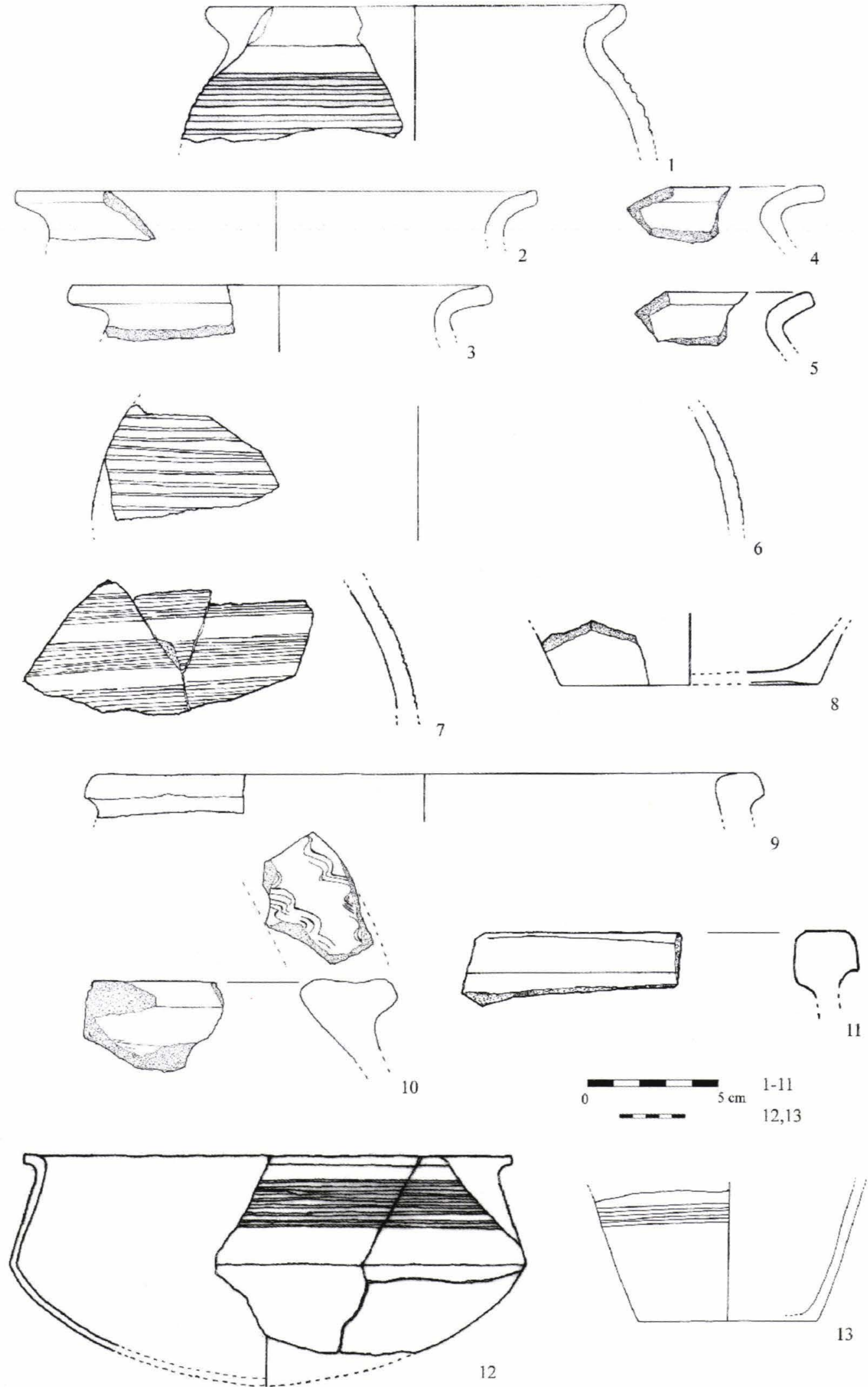

Pl. 14 - House 1 - pottery from the filling and the bigger hearth area. 

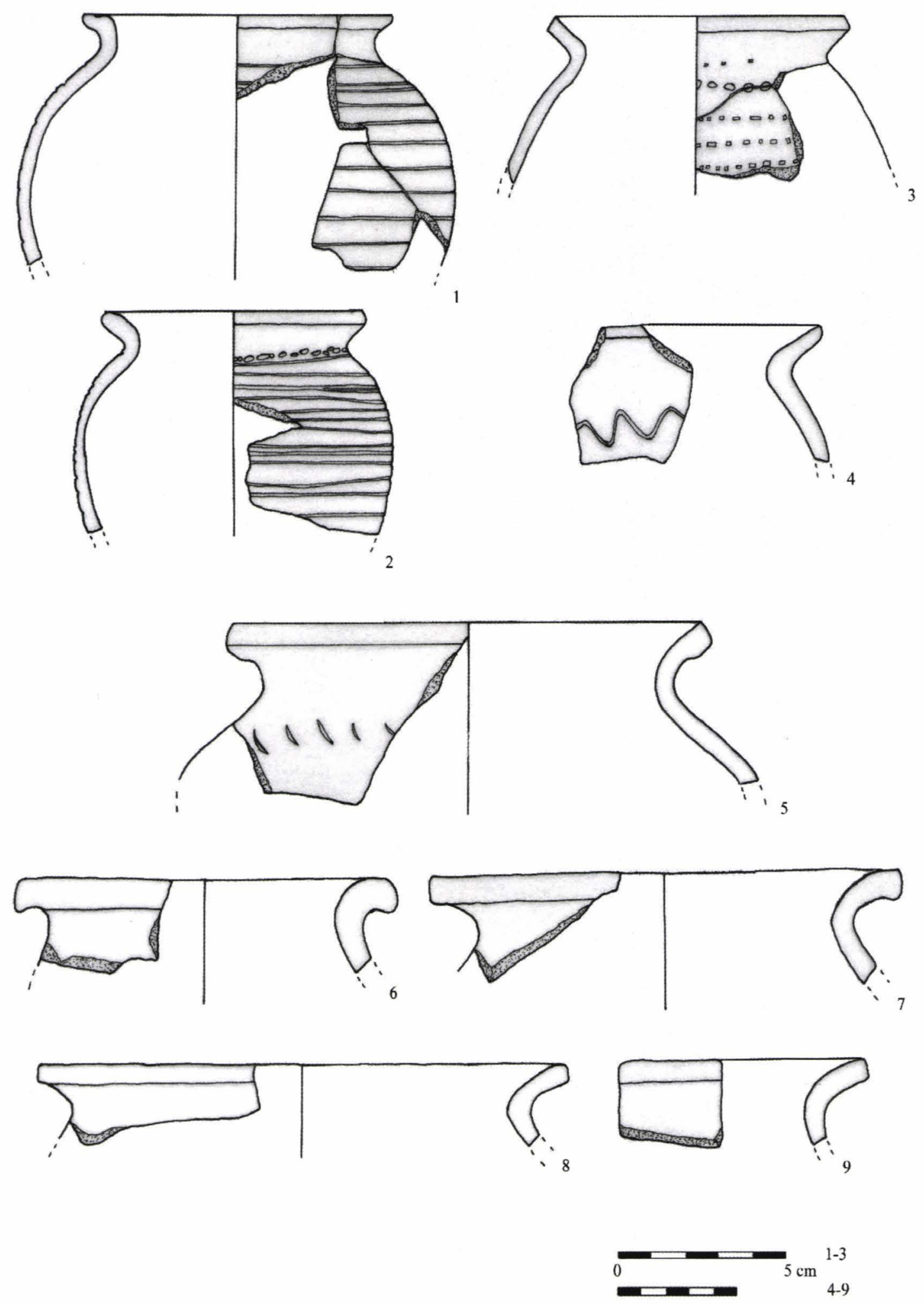

Pl. 15 - House 1- pottery from the filling. 


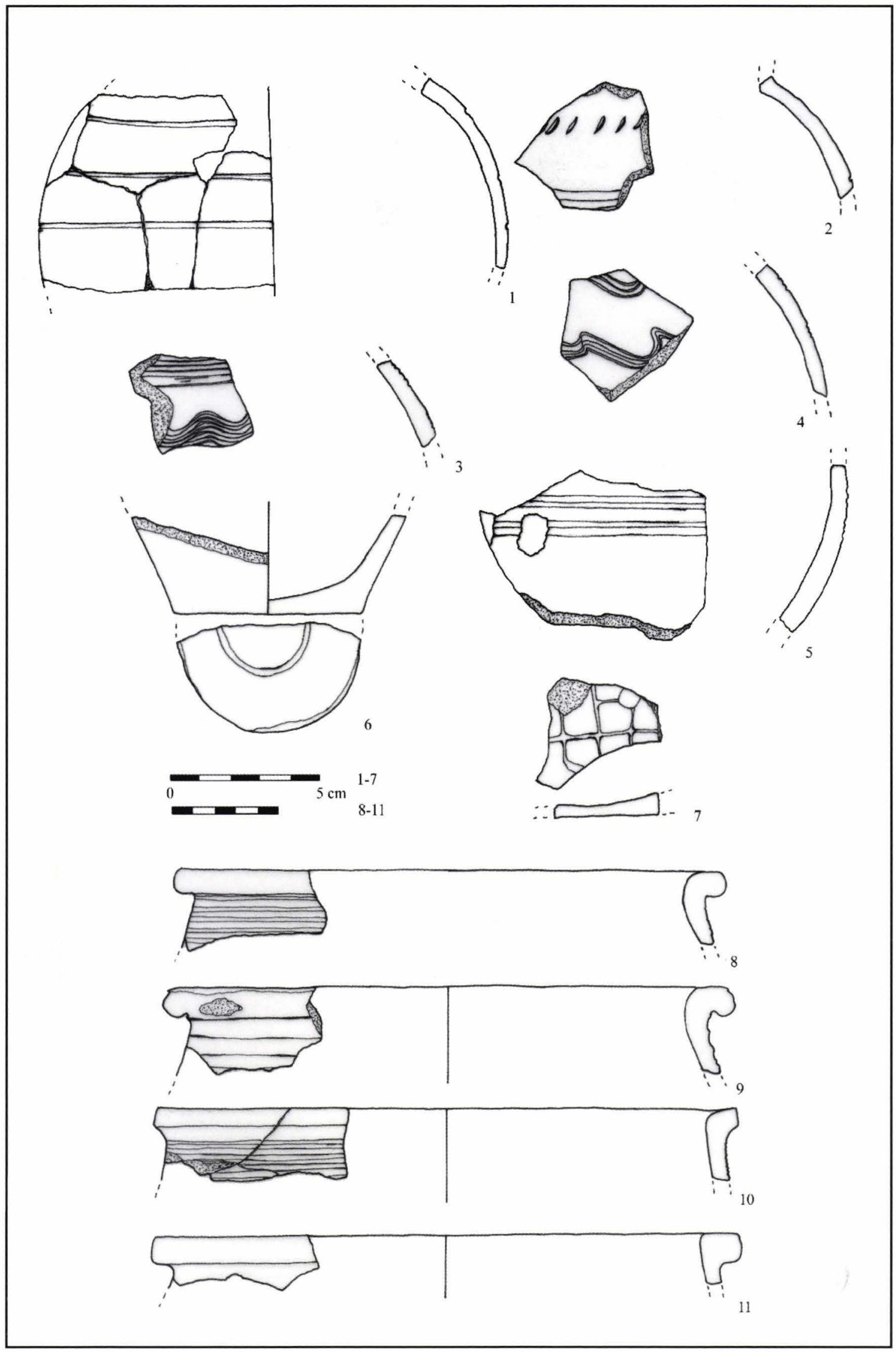

Pl. 16 - House 1 - pottery from the filling. 

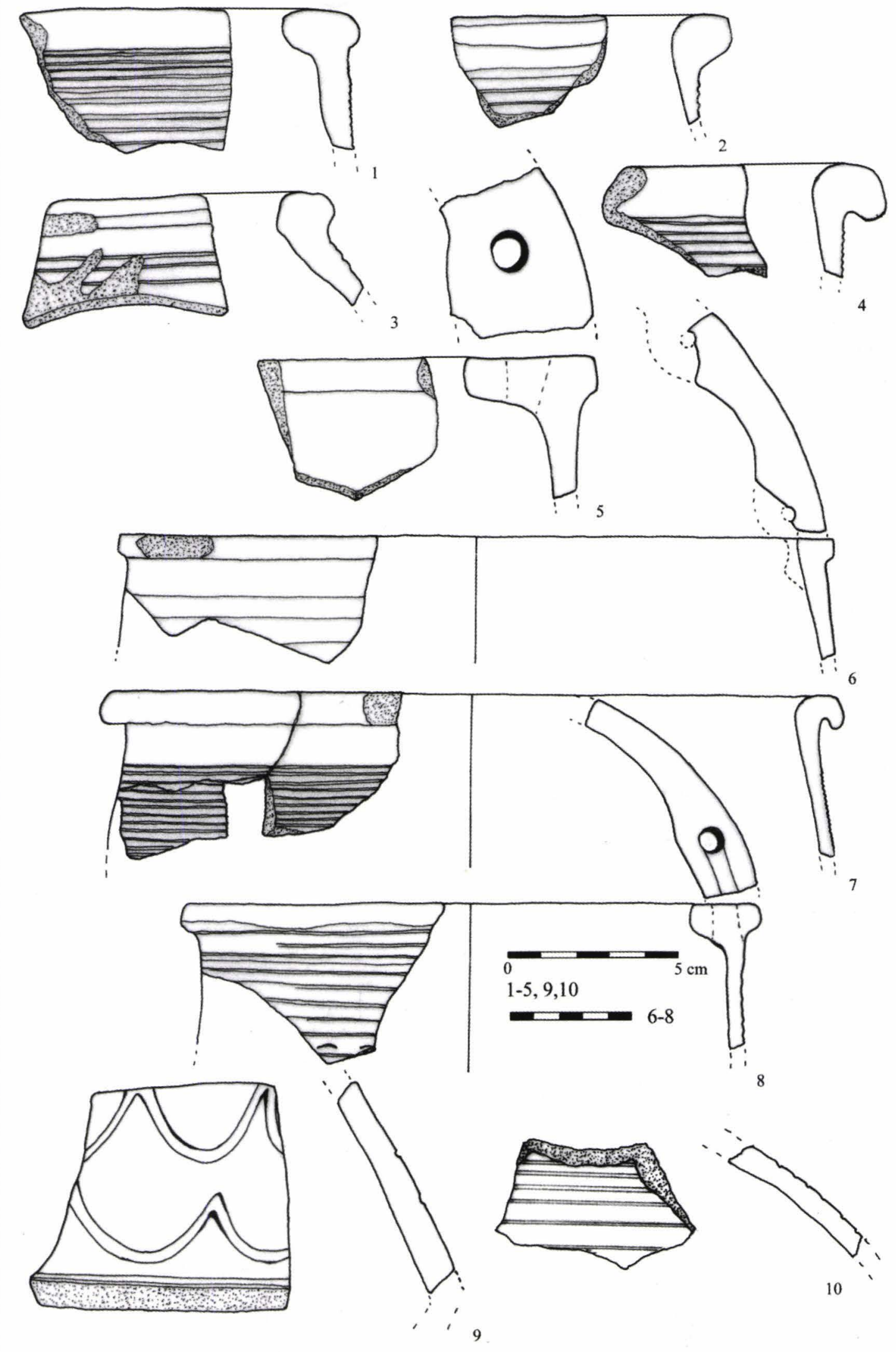

PI. 17 - House 1 - pottery from the filling. 

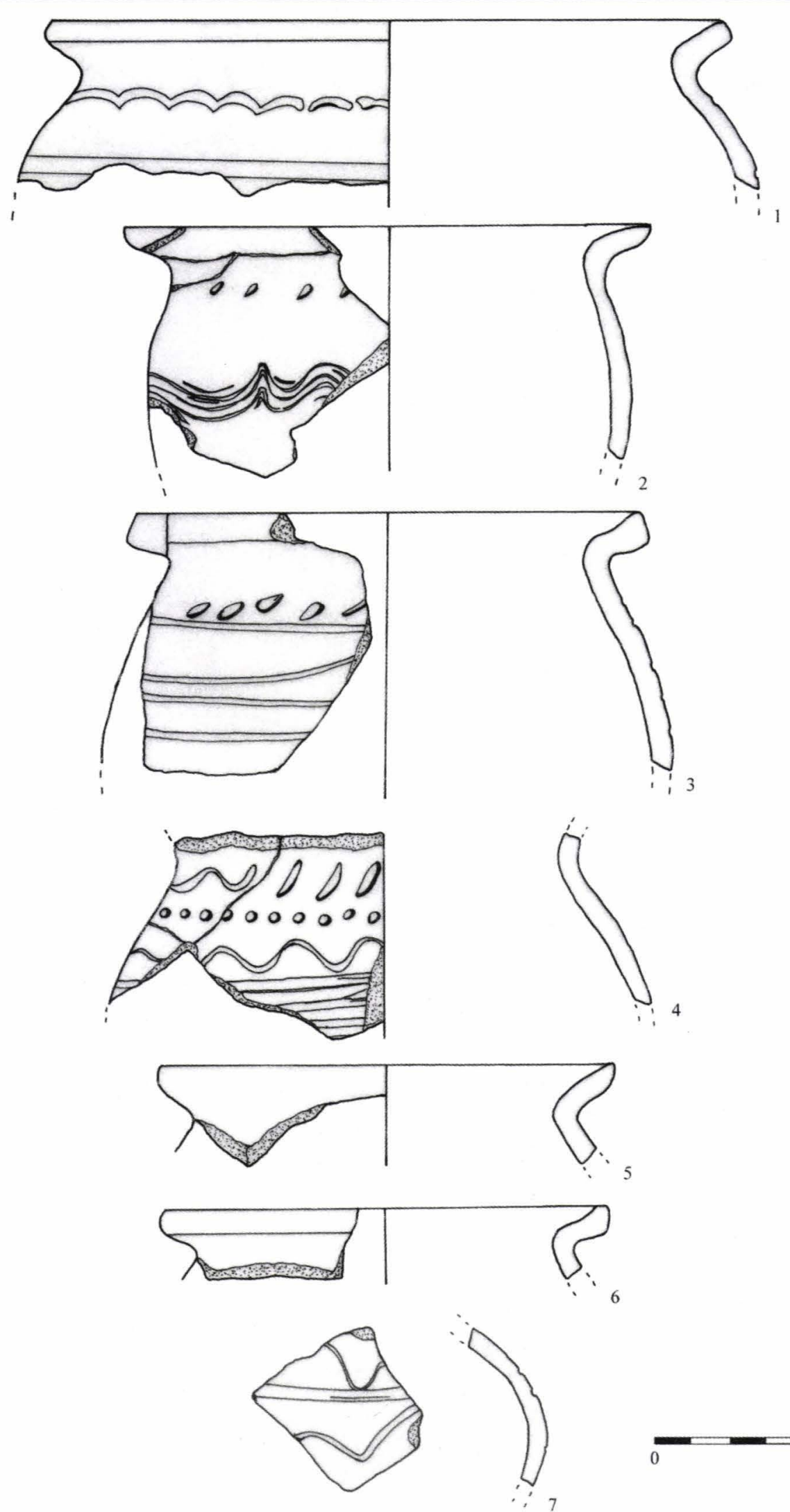

PI. 18 - House 1 - pottery from the floor and the hearth area. 

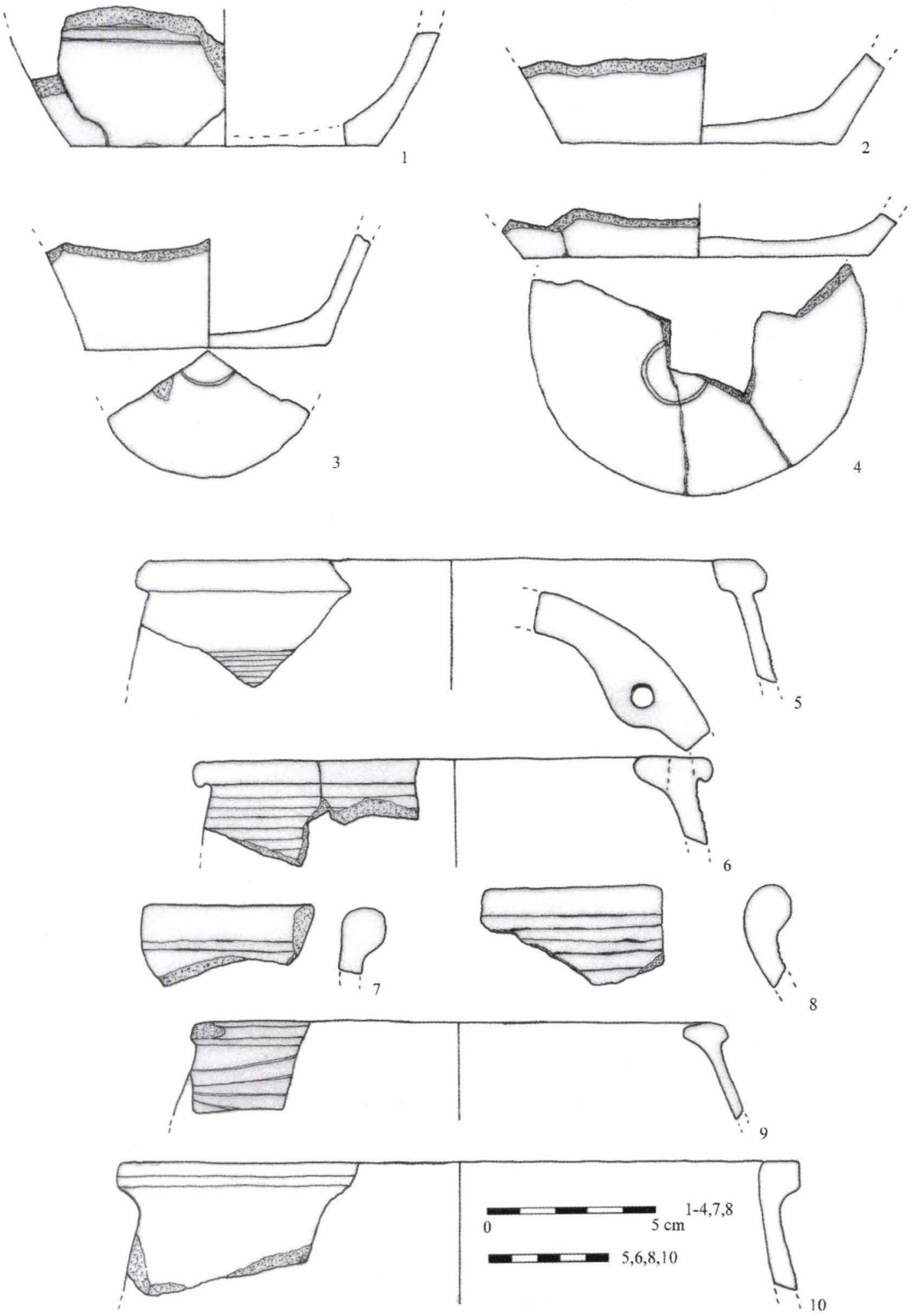

PI. 19 - House 1 - pottery from the floor and the hearth area. 

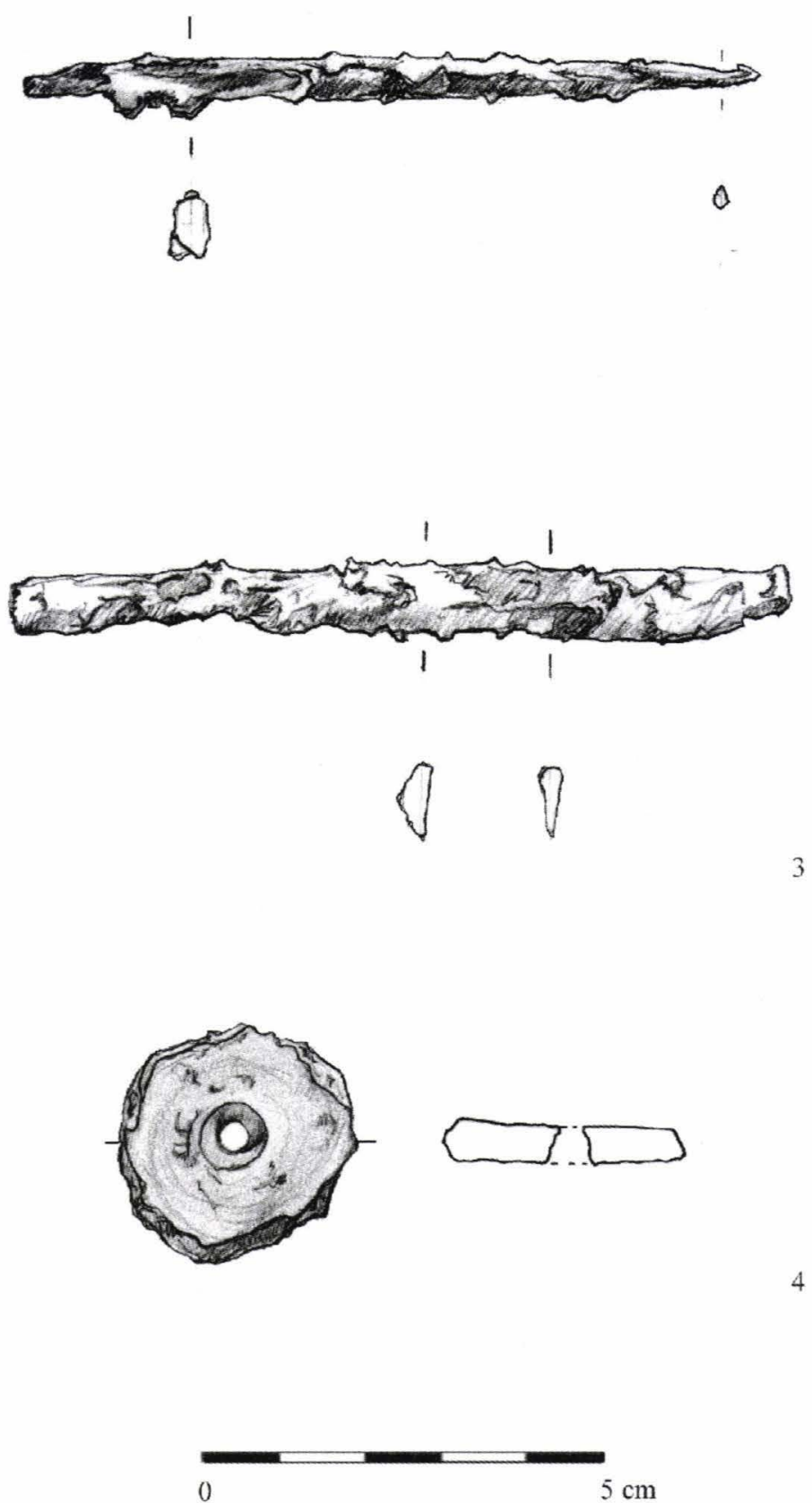

PI. 20 - House 1- 1. bone plating of a knife; 2-3. unidentified iron objects; 4. clay spindle-whorl. 

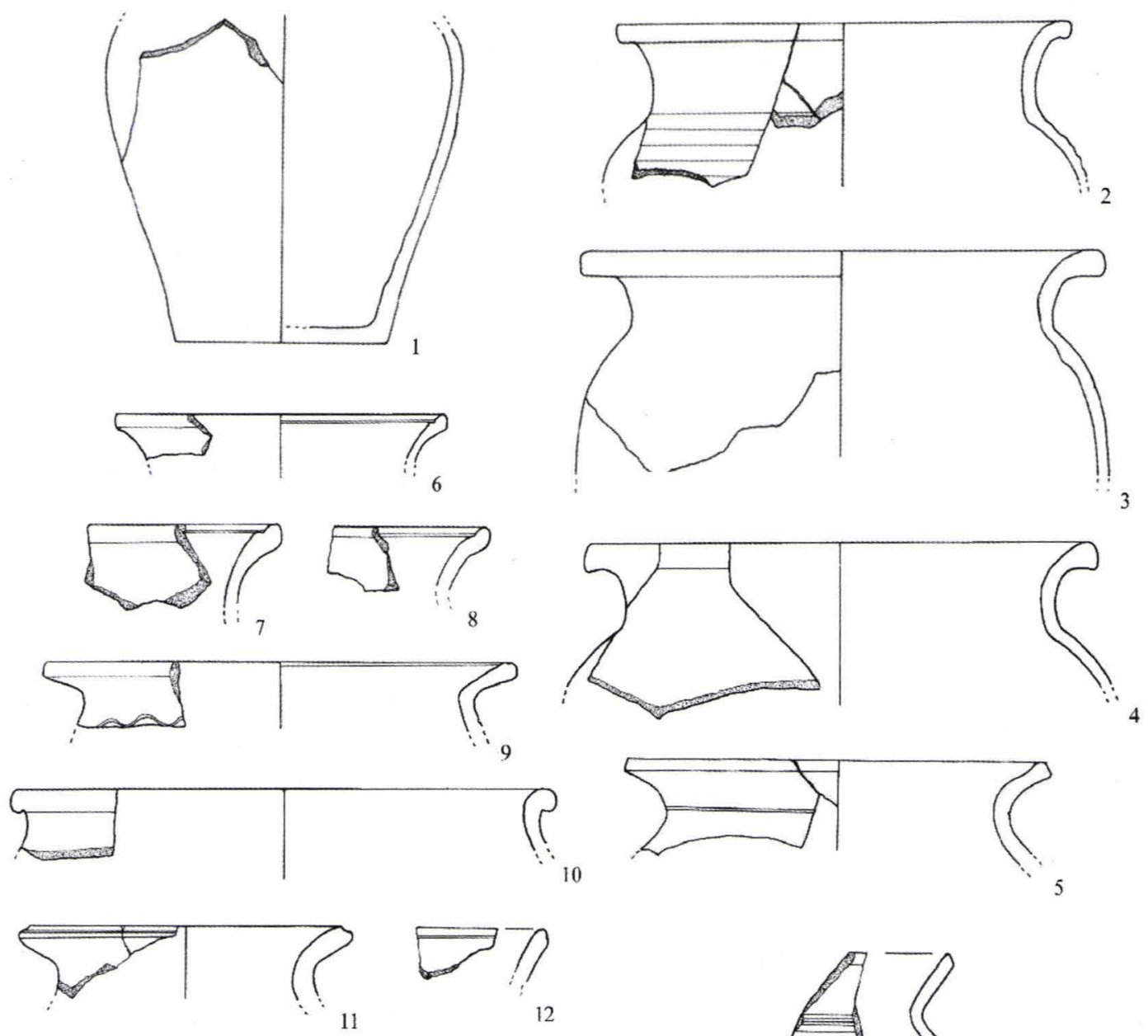

$\sum_{i=13}^{2}$
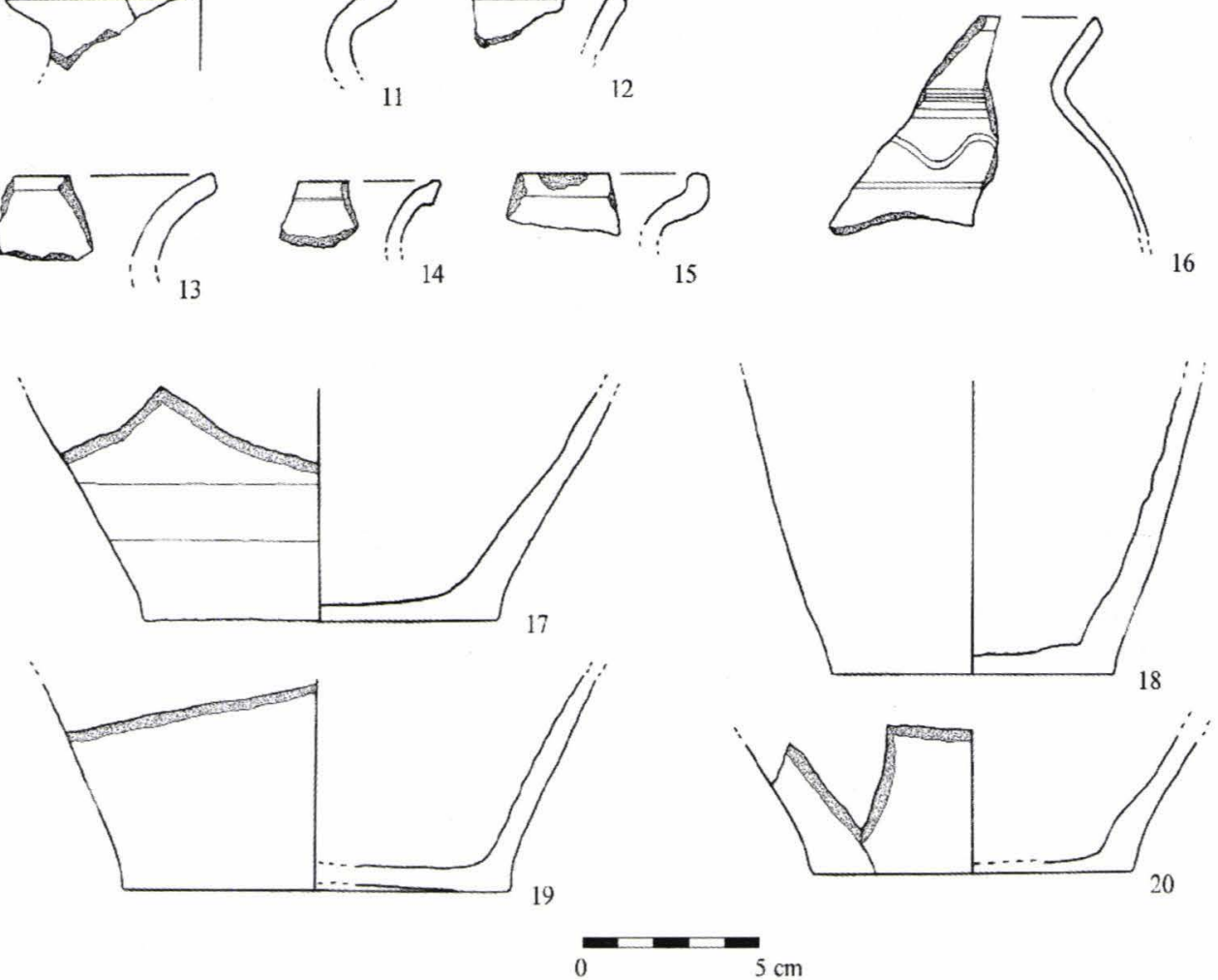

Pl. 21 - Pottery from the leyer around house 2. 

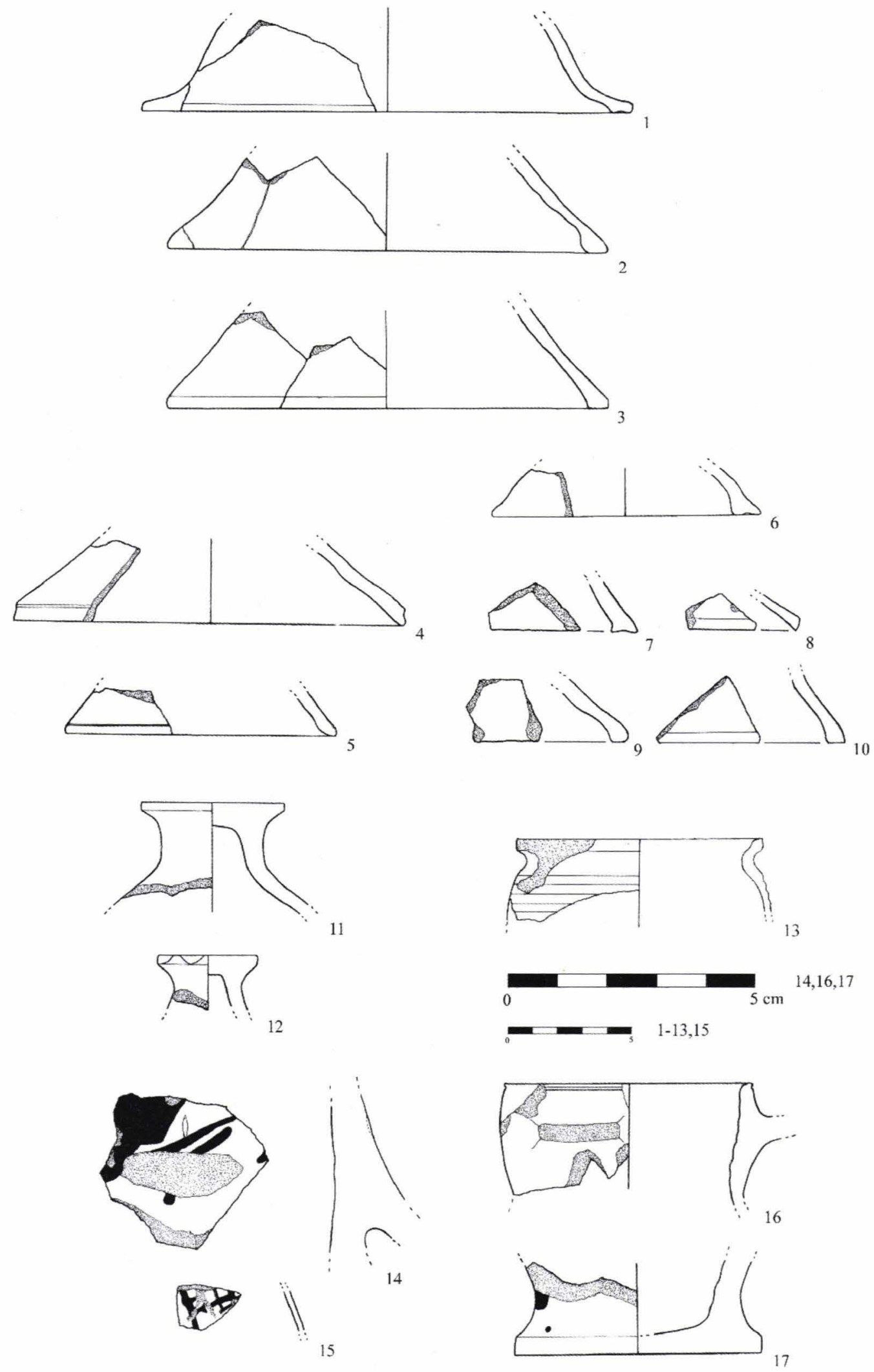

Pl. 22 - Pottery from the leyer around house 2. 


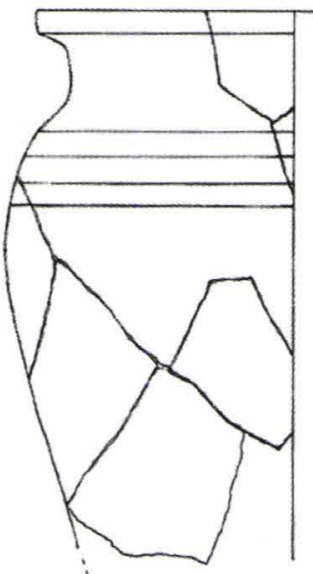

$? ?$

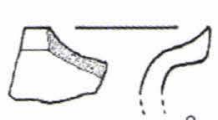

$\longrightarrow$
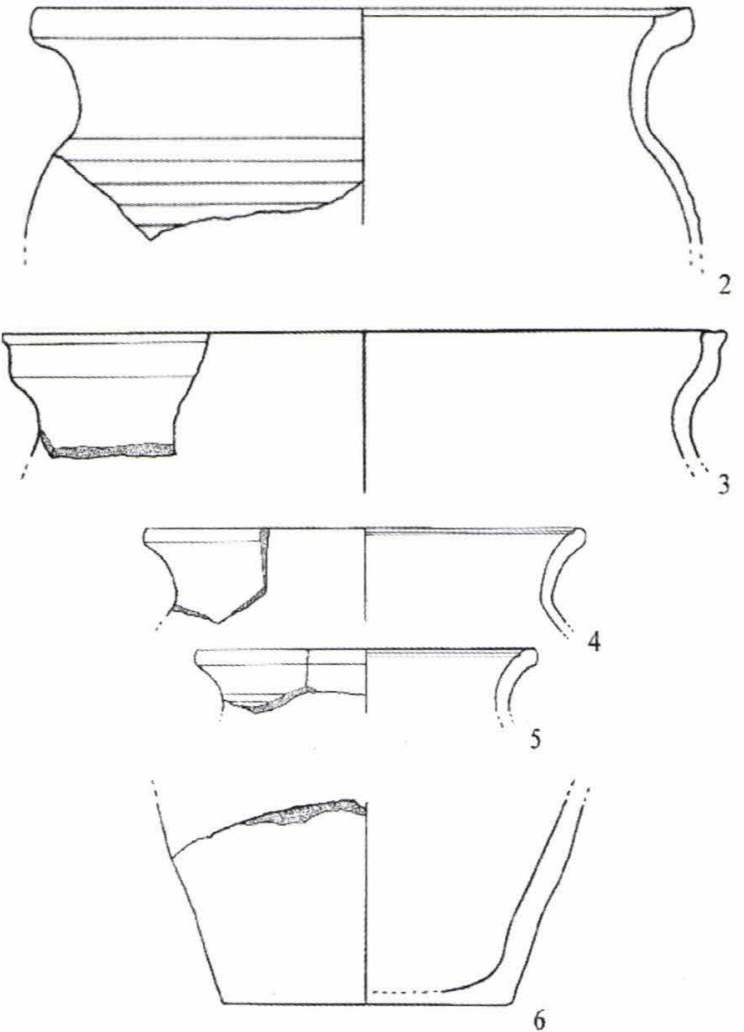

$=-5 \mathrm{~cm}$
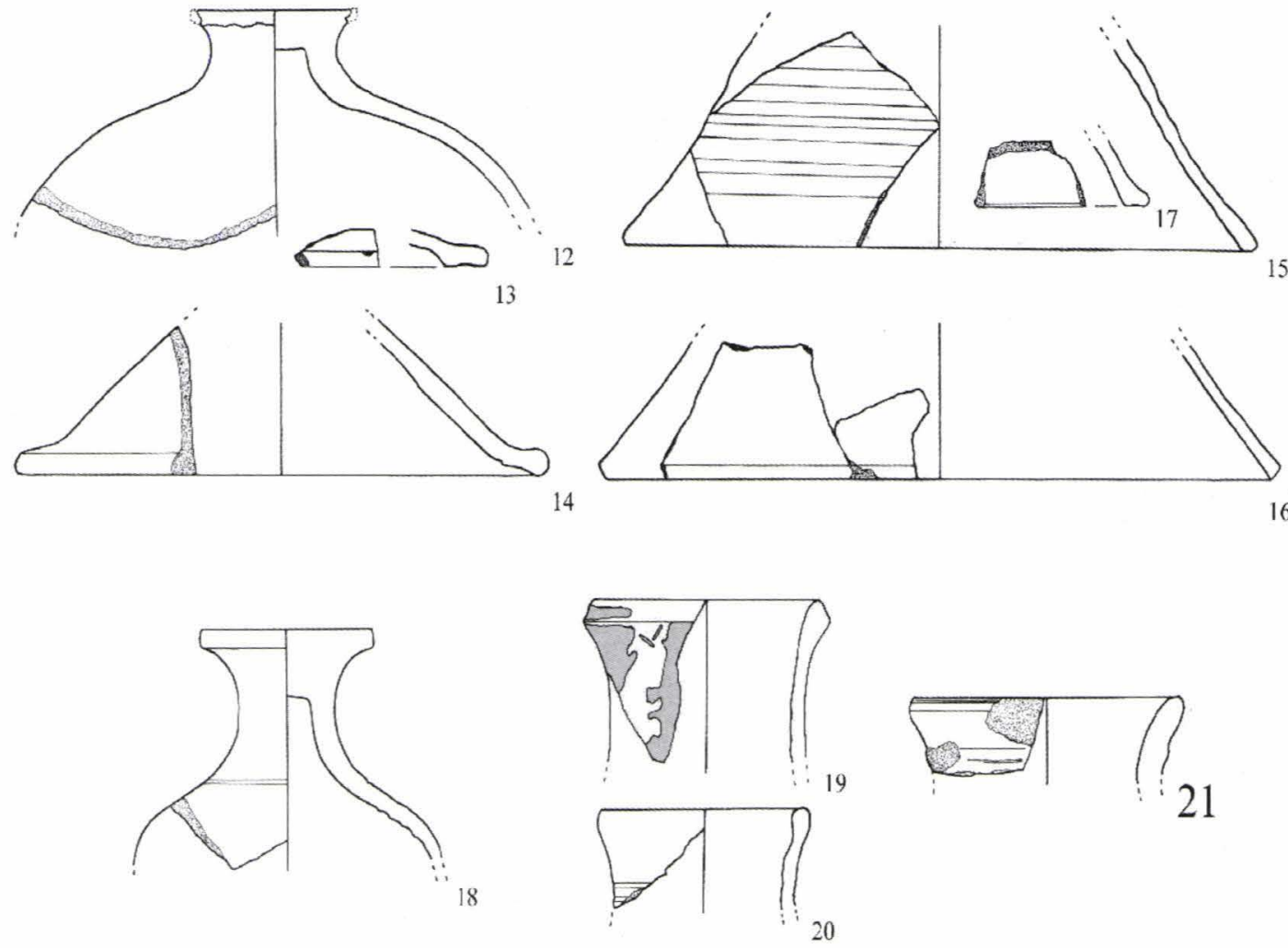

Pl. 23 - House 2, pottery from the lowest layer of the filling and from the floor. 

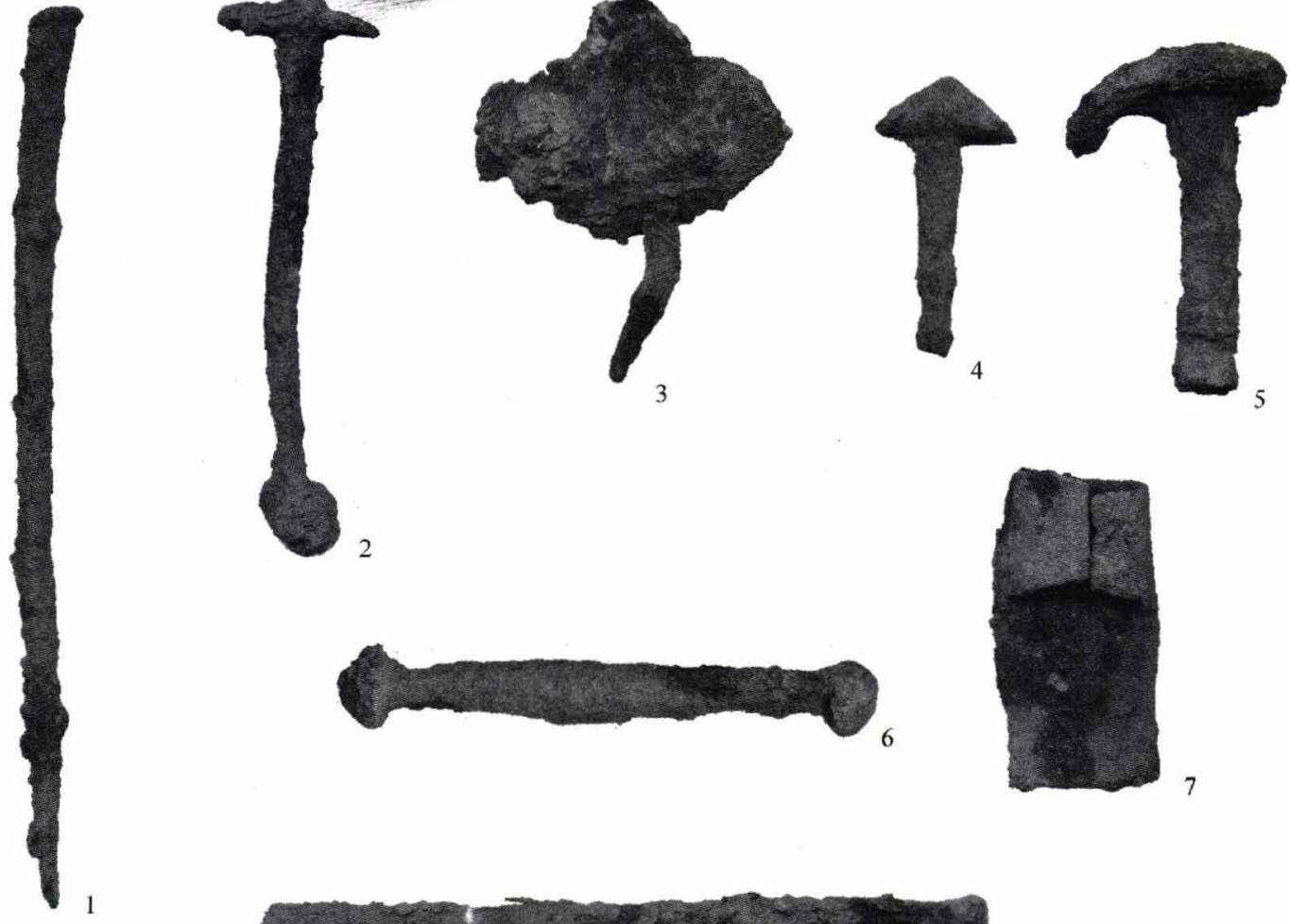

3
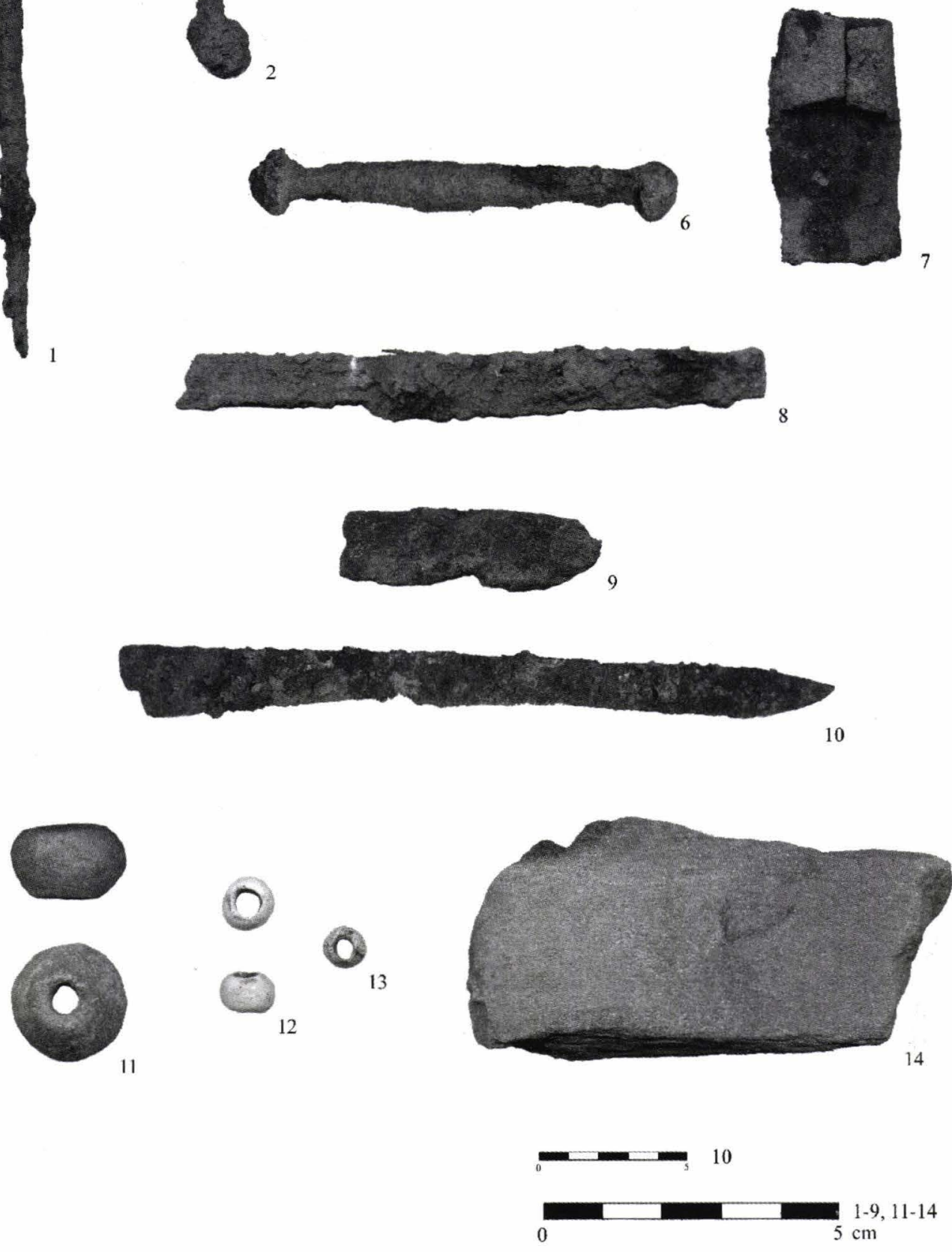

Pl. 24 - House 2 - 1, 6-7. tools; 2-5. nails; 8-10. Knives; 11. spindle-whorl; 12-13. glass pearls; 14. grindstone. 


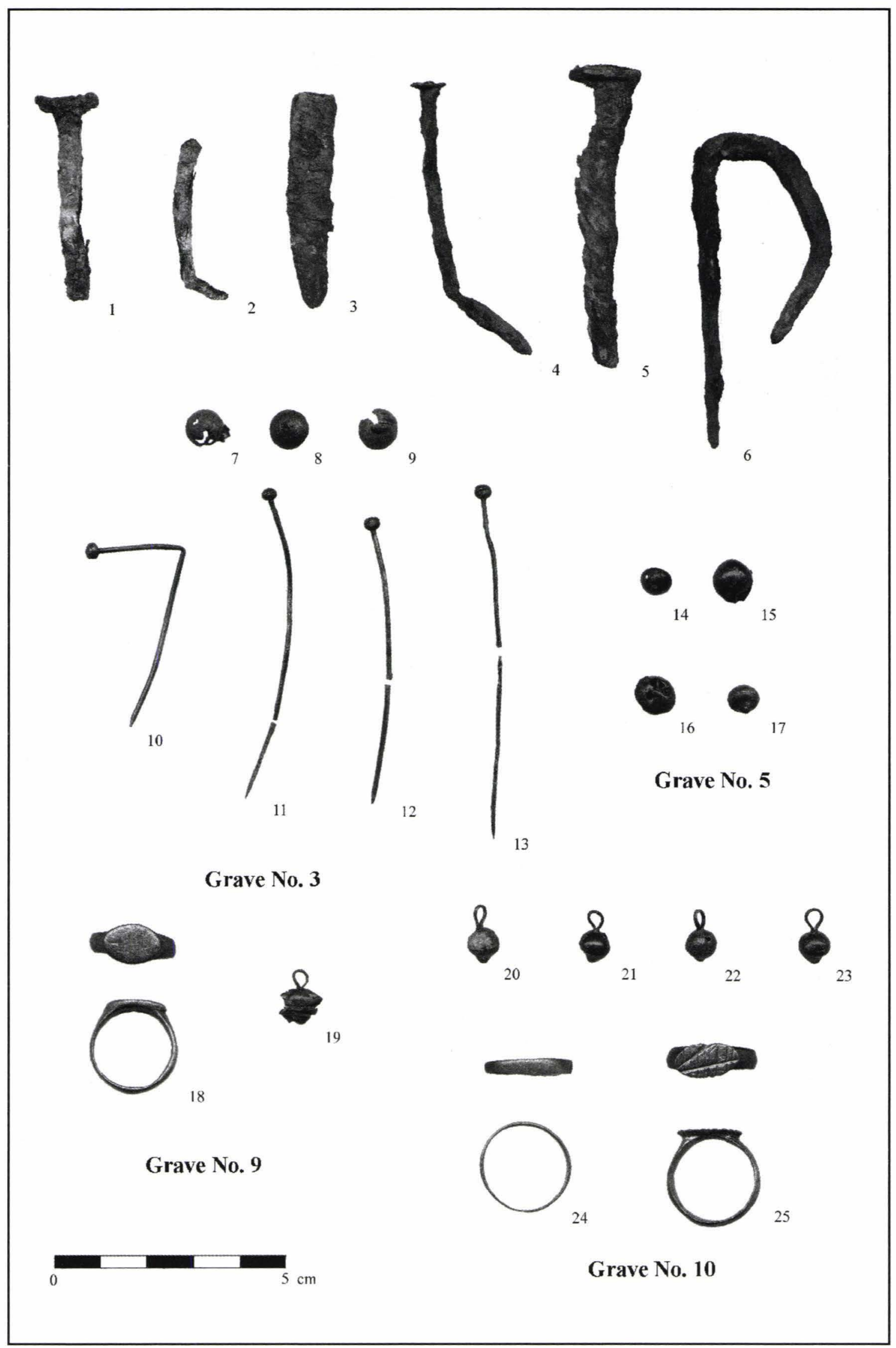

Pl. 25 - Necropolis, grave offerings. 

STUDII 
